Article

\title{
China's Conversion of Cropland to Forest Program for Household Delivery of Ecosystem Services: How Important is a Local Implementation Regime to Survival Rate Outcomes?
}

\author{
Michael T. Bennett ${ }^{1}$, Chen Xie ${ }^{2}$, Nicholas J. Hogarth ${ }^{3, *}$, Daoli Peng ${ }^{4}$ and Louis Putzel ${ }^{3}$ \\ 1 College of Environmental Sciences and Engineering, Peking University, Beijing 100871, China; \\ E-Mail: bennett.michaelt@gmail.com \\ 2 China National Forestry Economics and Development Research Center (FEDRC), \\ Beijing 100714, China; E-Mail: xiechen@forestry.gov.cn \\ 3 Center for International Forestry Research (CIFOR), Bogor 16115, Indonesia; \\ E-Mail: 1.putzel@cgiar.org \\ 4 Beijing Forestry University (BFU), Beijing 100080, China; E-Mail: dlpeng@bjfu.edu.cn \\ * Author to whom correspondence should be addressed; E-Mail: n.hogarth@cgiar.org; \\ Tel.: +62-251-862-2622; Fax: +62-251-862-2100.
}

Received: 2 February 2014; in revised form: 3 September 2014 / Accepted: 3 September 2014 / Published: 25 September 2014

\begin{abstract}
China's Conversion of Cropland to Forests Program (CCFP) is the world's largest afforestation-based Payments for Ecosystem Services (PES) program, having retired and afforested over 24 million ha involving 32 million rural households. Prior research has primarily focused on the CCFP's rural welfare impacts, with few studies on program-induced environmental improvements, particularly at the household level. In this study, data from a 2010 survey covering 2808 rural households from across China was analyzed using an interval regression model to explain household-reported survival rates of trees planted on program-enrolled cropland. In addition to household-level factors, we explore the influence of local conditions and institutional configurations by exploiting the wide diversity of contexts covered by the data set. We find that households with more available labor and more forestry experience manage trees better, but that higher opportunity costs for both land and labor have the opposite effect. We also find that the local implementation regime- e.g., the degree of prior consultation with participants and regular monitoring - has a strong positive effect on reported survivorship. We suggest that the level of subsidy support to participating households will be key to survivorship of trees in planted CCFP forests for some time to come.
\end{abstract}


Keywords: China; CCFP; sloping land conversion program; grain for green; payments for ecosystem services; rural smallholders; institutions; afforestation; forest restoration; agriculture; tree survival

\section{Introduction}

Catastrophic drought and flooding during 1997-1998 in China's two major river basins-the Yellow and Yangtze Rivers - catalyzed an important turning point in China's forest policy. The Yellow River witnessed a historic dry-out in 1997, whereby it did not reach the sea for an unprecedented 267 days. This was followed in the summer of 1998 by major floods in the Yangtze River Basin and the Songhua and Nen rivers in Northeast China, which are estimated to have claimed 3,000-4,000 lives and caused more than US\$12 billion in damages and lost production, including the loss of some five million hectares of crops [1-6]. In response, the central government launched a portfolio of programs - referred to as the "Six Key National Forestry Programs" - aimed at shifting the focus of the forest sector from its primary emphasis on extractive timber production to a more balanced approach involving concerted efforts to rehabilitate/restore and more sustainably manage forests for the ecological services they provide $[3,7]$. The largest, most important and most innovative of these programs is arguably the "Conversion of Cropland to Forests Program" (CCFP) [1].

Also known as "Grain-for-Green" or the "Sloping Land Conversion Program," the CCFP is the world's largest afforestation-based Payments for Ecosystem Services (PES) program. It involves over 32 million rural households and an investment of more than US\$42 billion (up until 2013), and has over 27 million ha of land enrolled [8]. Given the program's extent and size, and thus its potentially important impacts on the rural economy, previous work on the CCFP has primarily explored its rural welfare impacts - in terms of household income effects, labor allocation and structure of production [9-14] —as well as general implementation of the program, including land targeting and program cost effectiveness [1,10,15-17]. Some work has also looked at the program's potential impacts on grain output from reductions in crop area, which has been a recent concern of policymakers [18-20].

While such work has been important for gauging the long-term economic sustainability of CCFP, and by implication its environmental outcomes, it has had relatively little to directly say about program-induced provision of ecosystem services, in particular at the household level. Understanding how program incentives and other economic and social factors influence and induce rural households to provide targeted forest ecosystem services is critical for ensuring the CCFP's success, and for gauging the program's future. However, with the exception of Bennett and colleagues [8], work to date examining the CCFP's environmental dimensions has either been primarily qualitative in nature, has estimated future environmental benefits based on landscape scale models under hypothetical scenarios, or has used stated choice methods to estimate public willingness to pay for the program $[11,16,21]$.

To get at the question of program-induced household delivery of targeted forest ecosystem services, we use a large 2010 rural household data set collected from across China to examine the factors associated with the survival rate of household/program-planted trees. While clearly not quantifying the multiple ecosystem services provided by trees and forests, given the current availability of data at the 
national level the survival rate of program-planted trees is nonetheless an appropriate measure for examining the impacts of program incentives on household ecosystem service provision; it is the key indicator by which household CCFP implementation is evaluated and subsidy delivery determined. In other contexts, the survival rate of trees (in particular during the establishment phase, which is a 3-5 year period from when seed or seedlings are planted) is also used in program assessments [22,23].

The richness of the survey data set allows us to examine the impact of household characteristics, local institutions and socioeconomic context on survival rates. Implementation of the CCFP often varies significantly by locale, as is generally the case with many central government policies in China [24,25], and we exploit this to examine how the different configurations in a local de facto implementation regime are associated with reported survival rates.

\section{The Conversion of Cropland to Forests Program}

The CCFP was launched in 1999 via piloting in the three western provinces of Sichuan, Gansu, and Shaanxi, followed by full-scale implementation that expanded the program to 25 provinces by 2002 [26]. The policy originally targeted reducing soil erosion and flooding, but this has since been expanded to also emphasize local economic development and poverty alleviation, in line with an evolving national policy discourse [5,26]. To date, the program has converted 27.55 million ha of land into primarily tree-based plantations, of which 9.06 million ha (an area the size of Portugal) is retired and afforested cropland, 15.80 million ha is formally "wasteland" (also translated as "barren land", an official land category in China that includes marginal or sloping land that is deemed suitable to be developed into cropland), and 2.68 million ha is remote mountainous areas that have been sealed off to allow natural regeneration [8].

Significantly, the program directly pays participating rural households to retire and afforest or plant vegetative cover on their sloping or marginal cropland, and to ensure that these planted trees/grasses survive. Subsidy levels and duration depend on region and whether grasses, "ecological trees" (which can be either timber crops for harvesting or trees for providing ecological services) or "economic trees" (orchard crops, trees with medicinal value or trees that produce other types of NTFPs) are planted. According to the original 2003 plan, subsidy payments included a one-time fee of $750 \mathrm{CNY} / \mathrm{ha}$ for saplings or seeds, an annual living allowance of $300 \mathrm{CNY} / \mathrm{ha}$, and an annual grain/cash subsidy that was differentiated according to whether the participating household is in Yangtze River or Yellow River watershed regions ( $1 \mathrm{USD}=8.28 \mathrm{CNY}$ based on 2003 yearly average exchange rates). The subsidy rates were, and still are, the same irrespective of the type of tree or grass planted, with only the length of payments differing (see Table 1) [27]. The original plan also generally required that participating households afforest a roughly equal area of "wasteland," though the degree to which this was adhered to has varied by locale [1]. Phase II of the program, which commenced in 2007, has doubled the subsidy period, continuing both the living allowance and subsidies, with the latter now wholly in cash [27] (Table 1). 
Table 1. The Conversion of Cropland to Forests Program subsidy rates.

\begin{tabular}{|c|c|c|c|c|c|c|}
\hline \multirow[b]{2}{*}{ Subsidy Component } & \multicolumn{3}{|c|}{ Subsidy Rates } & \multicolumn{3}{|c|}{ Duration } \\
\hline & $\begin{array}{c}\text { Yangtze River } \\
\text { Watershed and } \\
\text { South China }\end{array}$ & or & $\begin{array}{c}\text { Yellow River } \\
\text { Watershed and } \\
\text { North China }\end{array}$ & $\begin{array}{l}\text { Ecological } \\
\text { Forests }\end{array}$ & $\begin{array}{l}\text { Economi } \\
\text { c Forests }\end{array}$ & Grasses \\
\hline \multicolumn{7}{|c|}{ PILOT PHASE (1999-2001): 412 counties in 20 provinces $^{1}$} \\
\hline \multicolumn{7}{|c|}{ ONE-TIME PAYMENT } \\
\hline Sapling/seedling Fee & \multicolumn{3}{|c|}{$750 \mathrm{CNY} / \mathrm{ha}$} & \multicolumn{3}{|c|}{ One-time, upon enrollment } \\
\hline \multicolumn{7}{|c|}{ ANNUAL PAYMENTS $^{2}$} \\
\hline (i) Living Allowance (Cash) & \multicolumn{3}{|c|}{$300 \mathrm{CNY} / \mathrm{ha}$} & \multirow{2}{*}{\multicolumn{3}{|c|}{ Payment length as yet undermined. }} \\
\hline (ii) Annual Subsidy (Grain) & $\begin{array}{c}2,250 \mathrm{~kg} / \mathrm{ha} \\
\text { (i.e., } 3,150 \mathrm{CNY} / \mathrm{ha})\end{array}$ & or & $\begin{array}{c}1,500 \mathrm{~kg} / \mathrm{ha} \text { (i.e. } \\
2,100 \mathrm{CNY} / \mathrm{ha})\end{array}$ & & & \\
\hline \multicolumn{7}{|c|}{ PHASE I-Full-scale implementation (2002-2007): 2500 counties in 25 provinces ${ }^{3}$} \\
\hline \multicolumn{7}{|c|}{ ONE-TIME PAYMENT } \\
\hline Sapling/seedling Fee & \multicolumn{3}{|c|}{$750 \mathrm{CNY} / \mathrm{ha}$} & \multicolumn{3}{|c|}{ One-time, upon enrollment } \\
\hline \multicolumn{7}{|c|}{ ANNUAL PAYMENTS } \\
\hline (i) Living Allowance (Cash) & \multicolumn{3}{|c|}{$300 \mathrm{CNY} / \mathrm{ha}$} & & & \\
\hline $\begin{array}{c}\text { (ii) Annual Subsidy } \\
\text { (Grain or cash equivalent value) }\end{array}$ & $\begin{array}{c}2,250 \mathrm{~kg} / \mathrm{ha} \\
\text { (i.e., } 3,150 \mathrm{CNY} / \mathrm{ha})\end{array}$ & or & $\begin{array}{c}\text { 1,500 kg/ha (i.e., } \\
2,100 \mathrm{CNY} / \mathrm{ha})\end{array}$ & 8 years & 5 years & 2 years \\
\hline
\end{tabular}

PHASE II (2008-2016)

CONTINUED ANNUAL PAYMENTS

(i) Living Allowance (Cash) $300 \mathrm{CNY} / \mathrm{ha}$

(ii) Annual Subsidy (Cash only) $1,575 \mathrm{CNY} / \mathrm{ha} \quad$ or $1,050 \mathrm{CNY} / \mathrm{ha}$

Source: State Forestry Administration, 2003; State Council, 2007; Average pilot phase exchange rate was 1 $\mathrm{USD}=8.28 \mathrm{CNY}$; average phase I exchange rate was $1 \mathrm{USD}=8.10 \mathrm{CNY}$; average phase II exchange rate was $1 \mathrm{USD}=6.52 \mathrm{CNY} ;{ }^{1}$ the pilot phase lasted three years; it was launched in 1999 in Sichuan, Gansu and Shanxi province. In 2000, the pilot extended to 188 counties of 17 provinces, and in 2001, it further expanded to some 400 counties of 20 provinces; ${ }^{2}$ Subsidy durations were not decided during the pilot phase; upon full-scale implementation, the length of time subsidies had already been delivered during the pilot phase was counted towards the formal subsidy lengths stipulated; ${ }^{3}$ Though a formal shift to cash-only subsidies was not stipulated until State Council (2007), State Council (2004) provided standards for converting grain to cash subsidies at the rate of $1.4 \mathrm{CNY} / \mathrm{kg}$, since many locales paid subsidies fully in cash by that time.

The CCFP targets a range of bundled forest ecosystem services, including timber, carbon sequestration, biodiversity habitat, landscape amenities and watershed services [1]. While program indicators for delivery of these have included land area afforested, types of land afforested (e.g., sloped and marginal land) and choice of trees to plant, the survival rates of program-planted and managed trees has been the most explicit program indicator utilized for evaluating service provision. During the pilot phase (1999-2002), subsidy delivery to households was stipulated to be conditional on achieving a survival rate for trees planted on enrolled land of $85 \%$ for Yangtze River basin regions, and $70 \%$ for Yellow River basin regions. This has since been revised to a nationwide standard of $75 \%$ for full-scale implementation [1]. However, this rate has varied by locale, often due to the tension faced by local governments between maintaining enthusiasm for the program and ensuring its rural welfare goals (i.e., by making sure households get program subsidies), while also achieving program environmental 
goals (i.e., by incentivizing achievement of survival rate targets by withholding a share of subsidies for sub-par outcomes) [24].

\section{Empirical Strategy}

Using a 2010 rural survey, we utilize household-reported survivorship of program-planted trees on the household CCFP-enrolled land to explore how household characteristics and local implementation regime are associated with household-level delivery of CCFP-targeted ecosystem services. In particular, we analyze household responses to the following question asked in the survey:

What has been the survival rate of the trees on your CCFP enrolled land thus far?
A. Over $90 \%$;
B. $70 \%-90 \%$;
C. $40 \%-70 \%$;
D. $10 \%-40 \%$;
E. Less than $10 \%$.

In the sample selected for analysis, $19 \%$ of household reported ranges of $70 \%$ and under (answers $\mathrm{C}$, $\mathrm{D}$ or $\mathrm{E}$ in the question above), $40 \%$ of households reported the $70 \%-90 \%$ range, while the remaining $41 \%$ of households reported over $90 \%$ (see Figure 1 below).

Figure 1. Regional distribution of survival rates of household conversion of cropland to forests program planted trees.



Note: The regional classifications in Figure 1 are not the SFA's formal delineations, but rather they are the regional indicator variables constructed for this analysis; "Northeast" consists of Beijing, Hebei, Shanxi, Inner Mongolia, Liaoning, Jilin and Heilongjiang provinces; "Northwest" consists of Tibet, Shaanxi, Gansu, Qinghai, Ningxia and Xinjiang provinces; "Southwest" covers Guangxi, Hainan, Chongqing, Sichuan, Guizhou and Yunnan provinces; and "Southeast" consists of Anhui, Jiangxi, Hubei and Hunan provinces. 
The data used for this analysis comes from a unique, one-time cross-sectional rural survey collected in 2010 and spanning much of China. The survey encompasses 2808 rural household CCFP participants, from 419 villages across 228 townships, 132 counties and 24 provinces, and was collected by 125 Beijing Forestry University (BFU) students upon returning to their home-towns/villages during the annual spring festival (see Figure 2 below). Student enumerators volunteered to participate in the survey, and numbered 159 at the beginning of the project and training. At the end of the fieldwork, 125 enumerators were able to provide completed surveys, from which the data for this analysis has been complied. Overall, the survey was well implemented, with strong support of the BFU student union and in close collaboration with the State Forestry Administration's National Forest Economics and Development Research Center (FEDRC), the agency responsible for monitoring and assessing the socioeconomic and environmental impacts of the CCFP and other key forestry programs. Arguably the most representative data set yet available for evaluating the CCFP, it is the result of one of a number of innovative initiatives and approaches utilized by the FEDRC to monitor this very large and regionally diverse program.

Figure 2. Conversion of cropland to forests program provincial coverage and survey data sample counties.

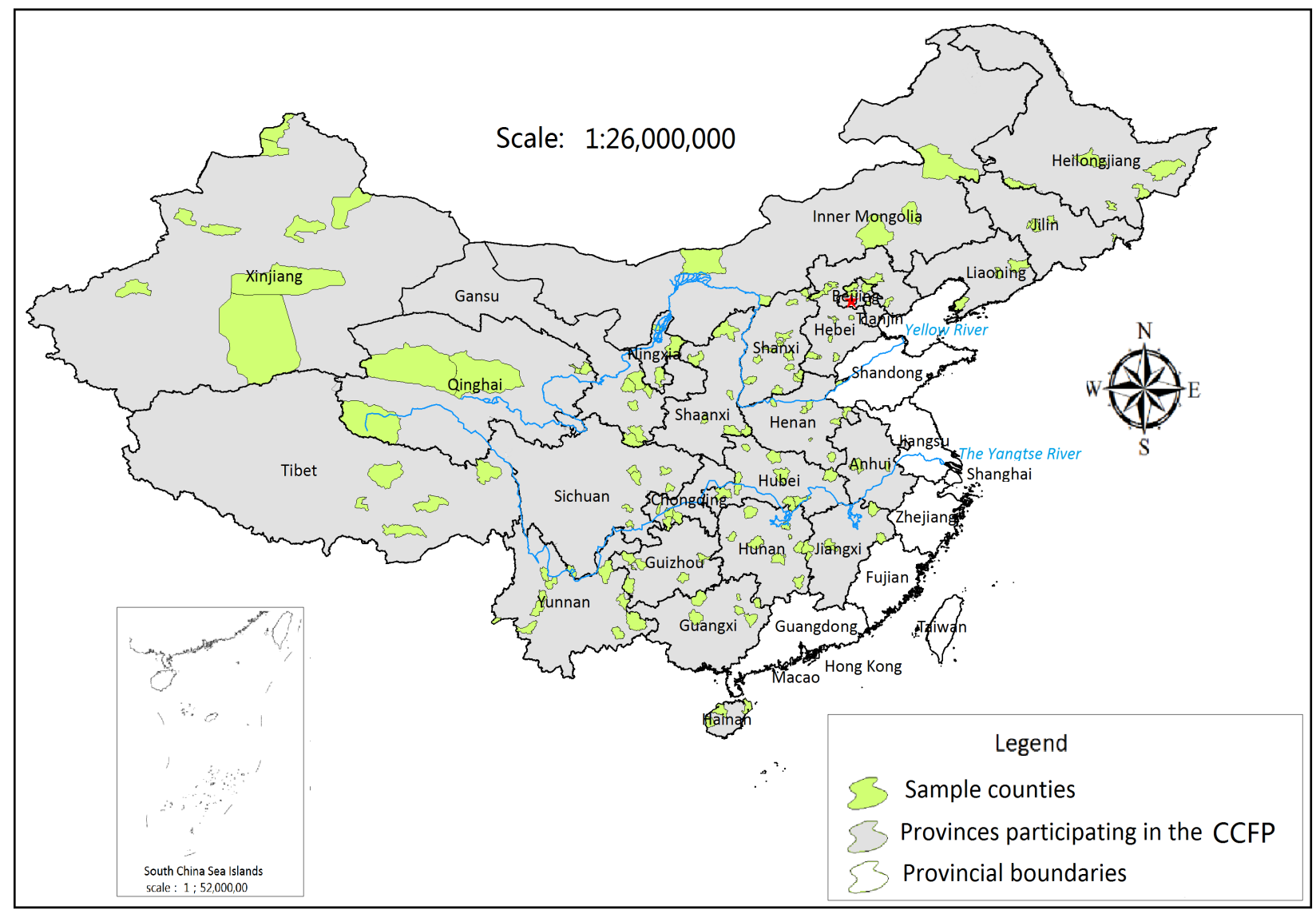

Map produced by Wang Jiang (Beijing Forestry University and FEDRC).

Students received basic enumerator training about data collection and household sampling methods prior to collecting survey data in their home regions in villages participating in the CCFP. Households were asked a range of questions regarding socioeconomic characteristics, income, employment, dependence on agriculture, forestry experience, local CCFP implementation regime, the characteristics of other related government policies in the locale, and a range of variables capturing program outcomes 
and household views regarding program strengths, weaknesses and induced local changes. Sample households were mostly randomly selected using official government lists of household names (Random sampling was likely not applied in all cases by students, though it is not possible to identify where this occurs in the data set). The completed, hand-written surveys were sent to BFU where data was entered into Excel before being handed over to the FEDRC for analyses. Of the 2808 surveys collected, 2635 households were selected for inclusion into the sample for analysis. Households excluded included: 114 with numerous missing explanatory variables, 30 with extremely large enrolled land area relative to the sample average, 122 that planted grasses on enrolled land, and 21 with missing responses to the survival rate question.

\subsection{Model}

Given the nature of the dependent variable, an interval regression model is used for the analysis. An interval regression is a generalized form of limited dependent variable models wherein the underlying dependent variable is unobserved, but the interval within which it falls is. Let the actual (i.e., unobserved) survival rate be characterized as $y^{*}=X \beta+\varepsilon$, where $X$ is a vector of explanatory variables, $\beta$ the vector of parameters for these, and $\varepsilon \sim N\left(0, \sigma^{2} \mathrm{I}\right)$. Let $y_{i}$ be the observed survival rate ranges within which $y^{*}$ falls in the data set, whereby:

$$
y_{i}=\left\{\begin{aligned}
y_{1} & \text { if } \theta_{1 \mathrm{LB}} \leq y^{*} \leq \theta_{1 \mathrm{UB}} \\
y_{2} & \text { if } \theta_{2 \mathrm{LB}}<y^{*} \leq \theta_{2 \mathrm{UB}} \\
& \vdots \\
y_{m} & \text { if } \theta_{m \mathrm{LB}}<y^{*} \leq \theta_{\mathrm{mUB}}
\end{aligned}\right.
$$

Since $y^{*} \in(0,100), \theta_{1 \mathrm{LB}}=0$ and $\theta_{\mathrm{mUB}}=100$. The log likelihood function for the model is

$$
\ln L=\sum_{n=1}^{N} \sum_{i=1}^{m} \pi_{n i} \cdot \log \left\{\Phi\left(\frac{\theta_{i \mathrm{UB}}-x_{n} \beta}{\sigma}\right)-\Phi\left(\frac{\theta_{i \mathrm{LB}}-x_{n} \beta}{\sigma}\right)\right\}
$$

where $\Phi(\cdot)$ is the standard normal cdf, and:

$$
\pi_{n i}=\left\{\begin{array}{c}
1 \text { if } y_{i} \text { is the interval observed for household } n \\
0 \text { otherwise. }
\end{array}\right.
$$

Of interest is the degree to which household characteristics, local implementation regime, and other related conditions are associated with the survival rates of household CCFP-planted trees. To explore this, the unobserved survival rate is modeled as:

$$
y^{*}=\alpha+\gamma \beta^{\gamma}+X^{H} \beta^{H}+X^{I} \beta^{I}+X^{C} \beta^{C}+\varepsilon
$$

Where $\alpha$ is the intercept term, $\gamma$ is a vector of regional indicator variables, $X^{H}$ is the vector of household characteristics, $X^{I}$ is a vector of local CCFP implementation regime characteristics, $X^{C}$ is a vector additional relevant local characteristics, $\left\{\beta^{\gamma}, \beta^{H}, \beta^{I}, \beta^{C}\right\}$ are the associated parameters and $\varepsilon$ the error term. 


\subsection{Explanatory Variables}

A range of model specifications were explored to examine how local institutional arrangements governing or related to CCFP implementation are associated with survival rates. First, a "naïve" model was estimated wherein local institutional regime and context is controlled for via household survey responses regarding this. Since such variables are likely correlated with both observed and unobserved household characteristics (e.g., aspects of human and social capital such as level of education and access to information, and psychological factors associated with household views on program implementation and outcomes) and therefore biased estimators of the actual local implementation regime, additional characterizations of the model were explored in which the local institutional variables were constructed from averages across households in the same locale.

Table 2 details sample household characteristics used as explanatory variables in the model. These falls into three categories: "Household Socioeconomic Characteristics"; "CCFP implementation"; and "Other Policy Impacts." Household socioeconomic characteristics were selected to capture the effects of household welfare and social capital (such as whether the household considers itself to be poor or rich within the village, and it is a member of an ethnic minority group), level and structure of income (whether agriculture is the main source of income, and the share of household labor that is "migrant," which usually means long-term), and rough measures of the household's human capital and experience (such as pre-CCFP per capita cropland and managed forest area, whether the household has worked before in afforestation, and whether the household has highly sloping cropland).

Table 2. Explanatory variables-household characteristics, 2010.

\begin{tabular}{|c|c|c|c|c|}
\hline \multirow{2}{*}{ Sample Household Characteristics } & \multicolumn{4}{|c|}{ Full Sample $(n=2656)$} \\
\hline & Mean & SD & Min & Max \\
\hline \multicolumn{5}{|c|}{ Household Socioeconomic Characteristics $\left(X^{H}\right)$} \\
\hline HH Labor Population (>15 Years Old) & 3.07 & 1.39 & 0 & 16 \\
\hline Respondent Has High-School or Above Education $(1=$ Yes $)$ & 0.17 & 0.38 & 0 & 1 \\
\hline Elementary School or Middle-School Education (1 = Yes) & 0.73 & 0.45 & 0 & 1 \\
\hline Has No Education or "Other" ( 1 = Yes $)$ & 0.09 & 0.28 & 0 & 1 \\
\hline Share of HH Labor that is "Migrant" & 0.35 & 0.35 & 0 & 1 \\
\hline HH PC Crop Area Pre-CCFP (ha) & 0.2 & 0.24 & 0 & 2.1 \\
\hline HH PC Forest Area Pre-CCFP (ha) & 0.06 & 0.37 & 0 & 13.3 \\
\hline Agriculture is HH's Main Income Source ( 1 = Yes) & 0.60 & 0.49 & 0 & 1 \\
\hline $\mathrm{HH}$ is Poor in the Village $(1=\mathrm{Yes})$ & 0.15 & 0.36 & 0 & 1 \\
\hline HH is Rich in the Village ( $1=$ Yes $)$ & 0.10 & 0.30 & 0 & 1 \\
\hline HH Members Worked Before in Afforestation $(1=$ Yes $)$ & 0.11 & 0.32 & 0 & 1 \\
\hline HH Has cropland $>25$ Degrees $(1=$ Yes $)$ & 0.42 & 0.49 & 0 & 1 \\
\hline Ethnic Minority? (1 = Yes) & 0.17 & 0.37 & 0 & 1 \\
\hline \multicolumn{5}{|c|}{ CCFP Implementation $\left(X^{H}, X^{I}\right.$ in the "naïve" model) } \\
\hline Years in CCFP & 6.21 & 1.96 & 2 & 10 \\
\hline HH CCFP Land Has Been Inspected Before $(1=$ Yes $)$ & 0.78 & 0.42 & 0 & 1 \\
\hline HH CCFP Land Is Formally Registered Agricultural Land ( $1=$ Yes $)$ & 0.77 & 0.42 & 0 & 1 \\
\hline
\end{tabular}


Table 2. Cont.

\begin{tabular}{|c|c|c|c|c|}
\hline \multirow{2}{*}{ Sample Household Characteristics } & \multicolumn{4}{|c|}{ Full Sample $(n=2656)$} \\
\hline & Mean & SD & Min & Max \\
\hline \multicolumn{5}{|c|}{ CCFP Implementation $\left(X^{H}, X^{I}\right.$ in the "naïve" model) } \\
\hline HH Has Other CCFP Afforestation Responsibilities $(1=$ Yes $) *$ & 0.25 & 0.43 & 0 & 1 \\
\hline HH "Probably/Partially Understands" the Policy & 0.50 & 0.50 & 0 & 1 \\
\hline HH "Doesn't Understand" the Policy & 0.17 & 0.38 & 0 & 1 \\
\hline HH "Knows" Their Responsibilities under CCFP ** & 0.85 & 0.36 & 0 & 1 \\
\hline HH Receives Subsidies in Cash & 0.22 & 0.41 & 0 & 1 \\
\hline HH Receives Subsidies via Smart Card & 0.69 & 0.46 & 0 & 1 \\
\hline CCFP Management Type is "Large HH" or "Large HH + Company" & 0.08 & 0.27 & 0 & 1 \\
\hline Timber Trees $(1=$ Yes $)$ & 0.41 & 0.49 & 0 & 1 \\
\hline Orchard Trees $(1=$ Yes $)$ & 0.39 & 0.49 & 0 & 1 \\
\hline Joint Type of Tree (e.g., Bamboo) $(1=$ Yes $)$ & 0.10 & 0.30 & 0 & 1 \\
\hline Shrubs $(1=$ Yes $)$ & 0.09 & 0.29 & 0 & 1 \\
\hline Had to Change Trees Types on CCFP Land? $(1=$ Yes $)$ & 0.13 & 0.33 & 0 & 1 \\
\hline CCFP Land Main Type Is Sloped ( $1=$ Yes $)$ & 0.59 & 0.49 & 0 & 1 \\
\hline CCFP Land Main Type Is Desertified ( $1=$ Yes $)$ & 0.14 & 0.35 & 0 & 1 \\
\hline CCFP Plots Average Distance from Home (km) & 1.86 & 3.42 & 0 & 35 \\
\hline CCFP Land Was Hit by Disaster ( $1=$ Yes $)$ & 0.08 & 0.28 & 0 & 1 \\
\hline Intercropping on CCFP Land ( $1=$ Yes $)$ & 0.19 & 0.39 & 0 & 1 \\
\hline HH Per Capita CCFP Land Area (ha) & 0.12 & 0.2 & 0 & 2 \\
\hline Average Yield of CCFP Land was High, Pre-CCFP (1 = Yes) & 0.08 & 0.28 & 0 & 1 \\
\hline \multicolumn{5}{|c|}{ Other Policy Impacts $\left(X^{H}, X^{I}\right.$ in the "naïve" model) } \\
\hline HH Forest Land is Collectively Managed & 0.07 & 0.26 & 0 & 1 \\
\hline Received Forest Certification (part of collective forest sect reforms) & 0.58 & 0.49 & 0 & 1 \\
\hline
\end{tabular}

* This can be either wasteland afforestation, or "closed-mountain" afforestation; ** these are indicated as "Forest Management" and "Afforestation" responsibilities.

CCFP implementation regime variables were selected to capture the effects of local program implementation regime (e.g., inspections, subsidies, enrollment intensity, and program land management aspects), ecological dimensions affecting survival rate outcomes (e.g., broad categories of tree types planted, enrolled land characteristics and pre-CCFP yield, whether replanting was necessary), and household level of understanding of program goals and responsibilities. Finally, under "Other Policy Impacts", two variables were also included to capture the impacts of the degree to which in the locale in question collective forest sector reforms were being implemented-which are ongoing reforms in China's southern collective forest sector whereby forest management rights are gradually being devolved to local communities and households.

To improve identification of local institutional characteristics, within-village averages across household responses for villages with at least 15 survey households were constructed as explanatory variables. While a relatively unified CCFP implementation regime possibly extends up to the county level in many locales across China, this is too large a unit of analysis for statistical identification of institutional effects and regional characteristics given the small available household samples per county in this data set, as well as the fact that such samples are generally clustered in particular villages rather than evenly spread throughout the county. Furthermore, the village is generally the most appropriate unit 
of analysis for institutional impacts on household behavior in rural China. For example, though national law stipulates set rights and tenure configurations for agricultural land, Rozelle and colleagues [28] find that in reality significant heterogeneity in de facto agricultural land rights exists across China at the village level, with this being the result of village governance factors.

Although not an ideal sample size, 15 was chosen as a cut-off point based on a balance between statistical rigor and minimal reduction in the total sample size. The household-level sample sizes for the samples constructed thus are 1675 and 1785, respectively. Restricting the sample to village or township clusters of higher than 15 households quickly reduced the overall sample sizes for analysis. To examine the degree to which such variables produced robust parameter estimates, specifications using similarly constructed township-level variables were also examined for comparison.

Table 3 details the methodology used for construction of the village-level variables from household survey responses, as well as the descriptive statistics of the variables so constructed. In total, 92 villages had at least 15 survey households from which to construct variables, while 93 townships had such. Depending on the particular institutional or economic characteristic being captured, the mean, median or maximum of household-level responses for the village sample were used as appropriate. Sample means were used to represent a village's propensity to have a particular characteristic or condition while sample medians of household-level $0 / 1$ indicator variables were used as discrete indicators of a village condition or institution as appropriate. The number of years the village had been implementing the CCFP is estimated as the maximum number from the household sample in that village.

Finally, to control for systematic differences in regional ecological and economic conditions that could affect survival rates, regional indicator variables were constructed to divide the sample roughly into the four regions: "Northeast" (Beijing, Hebei, Shanxi, Inner Mongolia, Liaoning, Jilin and Heilongjiang provinces), "Northwest" (Tibet, Shaanxi, Gansu, Qinghai, Ningxia and Xinjiang provinces), "Southwest" (Guangxi, Hainan, Chongqing, Sichuan, Guizhou and Yunnan provinces) and "Southeast" (Anhui, Jiangxi, Hubei and Hunan provinces). For the sample analyzed, 36\% is in the northeast, $21 \%$ is in the northwest, $29 \%$ is in the southwest, and $14 \%$ is in the southeast.

\section{Results and Discussion}

Table 4 below presents the interval regression model results. Specification (1) only includes household characteristics, while (2), (3) and (6) are the "naïve" models wherein only household-level responses are used as indicators of local implementation regime. Specifications (4)-(5) and (7)-(8) utilize the constructed village and township-level variables, respectively, to capture local institutional and other characteristics. Specifications (3) and (6) were included to examine in what way restricting estimation to the village and township samples affects the parameter estimates of the "naïve" model. 
Table 3. Explanatory variables - constructed village institutional, conversion of cropland to forests program implementation and other characteristics, 2010.

\begin{tabular}{|c|c|c|c|c|c|c|c|c|c|c|}
\hline \multirow{2}{*}{ Constructed Village Characteristics } & \multirow{2}{*}{ Statistic Used ${ }^{+}$} & \multirow{2}{*}{ Interpretation } & \multicolumn{4}{|c|}{ Village Sample $(n=92)$} & \multicolumn{4}{|c|}{ Township Sample $(n=93)$} \\
\hline & & & Mean & $S D$ & Min & Max & Mean & $S D$ & Min & Max \\
\hline \multicolumn{11}{|l|}{ CCFP Implementation Regime $\left(X^{I}\right)$} \\
\hline $\begin{array}{l}\text { Number of Years Village has Been Implementing } \\
\text { CCFP }\end{array}$ & Max & $\begin{array}{l}\text { (A) Village began } \\
\text { implementing CCFP since at } \\
\text { least the earliest enrollment } \\
\text { year reported by village } \\
\text { households in the sample. }\end{array}$ & 7.24 & 1.79 & 2 & 10 & 7.38 & 1.79 & 2 & 10 \\
\hline$\ldots=$ Share of households in the village & \multirow{9}{*}{ Mean } & \multirow{9}{*}{$\begin{array}{l}\text { (B) Capturing village } \\
\text { propensity to have this } \\
\text { characteristic, measured as } \\
\text { share of village households in } \\
\text { the sample reporting this. }\end{array}$} & & & & & & & & \\
\hline ... with CCFP land inspected & & & 0.81 & 0.29 & 0 & 1 & 0.81 & 0.29 & 0 & 1 \\
\hline$\ldots$ with intercropping on CCFP land & & & 0.16 & 0.24 & 0 & 1 & 0.17 & 0.24 & 0 & 1 \\
\hline ... that "understand" the policy & & & 0.35 & 0.32 & 0 & 1 & 0.36 & 0.33 & 0 & 1 \\
\hline ... that "probably/partially understand" the policy & & & 0.51 & 0.31 & 0 & 1 & 0.49 & 0.31 & 0 & 1 \\
\hline ... that "do not understand" the policy & & & 0.15 & 0.24 & 0 & 0.93 & 0.15 & 0.25 & 0 & 0.93 \\
\hline ... "know their responsibilities" under $\mathrm{CCFP}^{++}$ & & & 0.86 & 0.22 & 0.03 & 1 & 0.87 & 0.20 & 0.03 & 1 \\
\hline$\ldots$ with other CCFP afforestation responsibilities ${ }^{+++}$ & & & 0.27 & 0.37 & 0 & 1 & 0.30 & 0.38 & 0 & 1 \\
\hline$\ldots$ that received full subsidies & & & 0.78 & 0.33 & 0 & 1 & 0.77 & 0.32 & 0 & 1 \\
\hline $\begin{array}{l}\text { Subsidies are Publically Shown in the Village or } \\
\text { Township }\end{array}$ & \multirow{3}{*}{ Median } & \multirow{3}{*}{ See (C) below. } & 0.46 & 0.42 & 0 & 1 & 0.47 & 0.41 & 0 & 1 \\
\hline Most Households Receive Subsidies in Cash & & & 0.20 & 0.40 & 0 & 1 & 0.21 & 0.39 & 0 & 1 \\
\hline Most Households Receive Subsidies by Smart Card & & & 0.78 & 0.41 & 0 & 1 & 0.71 & 0.43 & 0 & 1 \\
\hline
\end{tabular}


Table 3. Cont.

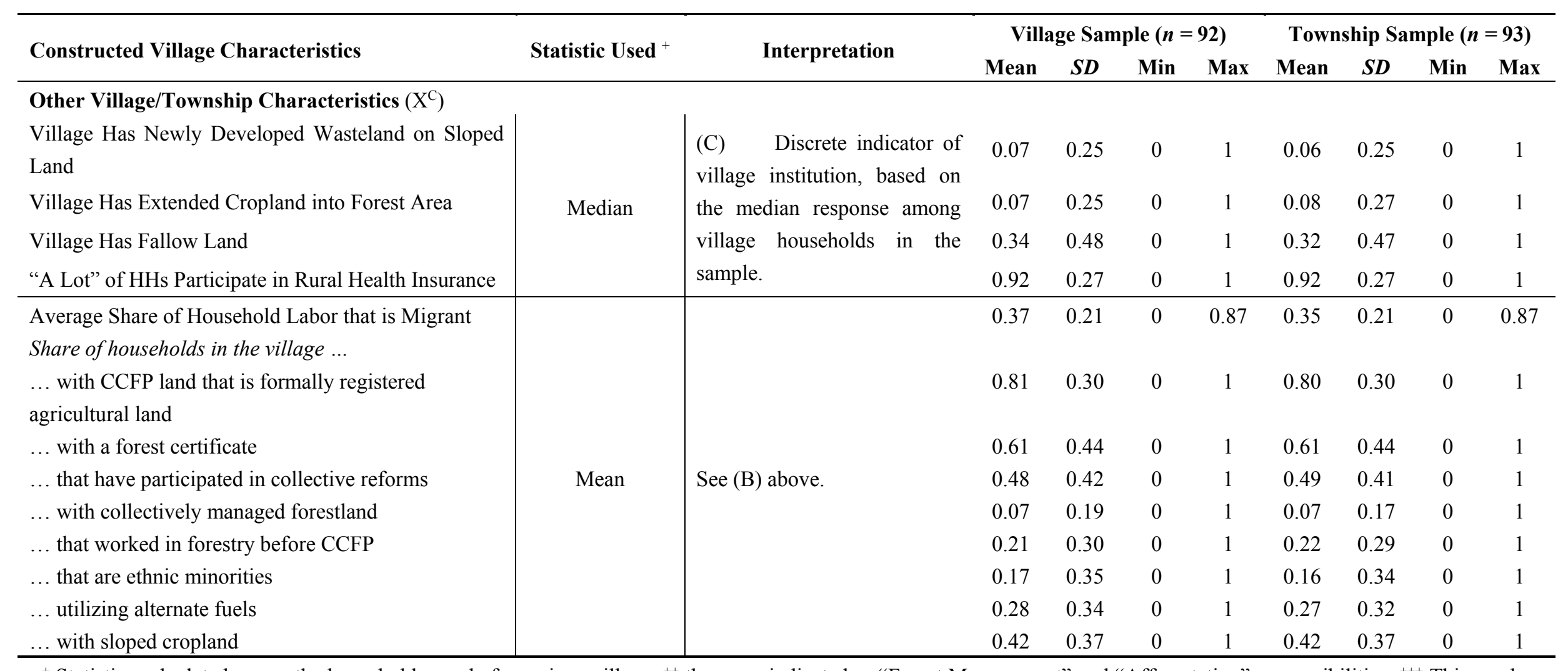

+ Statistics calculated across the household sample for a given village; ${ }^{++}$these are indicated as "Forest Management" and "Afforestation" responsibilities; ${ }^{+++}$This can be either wasteland afforestation, or "closed-mountain" afforestation. 
Table 4. Interval regression model of tree survivorship on household conversion of enrolled land form the cropland to forests program.

\begin{tabular}{|c|c|c|c|c|c|c|c|c|}
\hline \multirow{4}{*}{ Variable } & \multicolumn{8}{|c|}{ Effect on Survival Rate $(\%)^{+}$} \\
\hline & \multirow{2}{*}{\multicolumn{2}{|c|}{$\begin{array}{l}\text { Only Household- Level } \\
\qquad(n=\mathbf{2 6 3 5})\end{array}$}} & \multicolumn{6}{|c|}{ Conditioning on Local Characteristics, Calculated as Averages at .... } \\
\hline & & & \multicolumn{3}{|c|}{$\ldots$ Village-Level $(n=1675)$} & \multicolumn{3}{|c|}{...Township-Level $(n=1785)$} \\
\hline & (1) & (2) & (3) & (4) & (5) & (6) & (7) & (8) \\
\hline Constant & $\mathbf{7 0 . 0 5 0} * * *$ & $64.492 * * *$ & $66.240 * * *$ & $72.571 * * *$ & $68.076 * * *$ & $67.715 * * *$ & $\mathbf{8 1 . 8 9 0} * * *$ & $\mathbf{8 1 . 8 3 7 * * *}$ \\
\hline \multicolumn{9}{|c|}{ Regional Indicators } \\
\hline Northwestern Province & -3.535 & -3.780 & -1.221 & -0.228 & 0.868 & -1.448 & -1.278 & -0.566 \\
\hline Southwestern Province & $-4.390 * *$ & $-3.457 *$ & 0.059 & -0.094 & -0.313 & 0.308 & 0.586 & -0.204 \\
\hline Southeastern Province & -0.631 & 1.116 & 2.132 & 4.310 & 3.750 & 2.473 & 4.507 & 3.139 \\
\hline \multicolumn{9}{|c|}{ Household Socioeconomic Characteristics } \\
\hline Household Labor Population ( $>15$ Years Old) & 0.530 & 0.408 & 0.196 & 0.001 & 0.002 & 0.144 & -0.067 & 0.005 \\
\hline $\begin{array}{l}\text { Respondent Has High School or Above Education }(1= \\
\text { Yes) }\end{array}$ & 0.017 & -0.376 & 0.940 & 0.873 & 0.945 & 1.332 & 0.995 & 1.320 \\
\hline $\begin{array}{l}\text { Respondent Has No Education or "Other" } \\
\quad(1=\text { Yes })\end{array}$ & -0.468 & 0.489 & 0.028 & 0.084 & 0.685 & 0.614 & 0.608 & 0.883 \\
\hline Share of Household Labor that is "Migrant" & -0.013 & -0.015 & -0.022 & 0.018 & 0.018 & -0.017 & 0.018 & 0.016 \\
\hline Household Per Capita Crop Area Pre-CCFP (ha) & -3.417 & -4.099 & -8.065 & -6.461 & -6.251 & -7.127 & -5.401 & -5.824 \\
\hline Household Per Capita Forest Area Pre-CCFP (ha) & $1.676 * * *$ & $2.082 * * *$ & $2.603 * *$ & $2.873 * * *$ & $2.512 * *$ & $2.247 * * *$ & $2.233 * * *$ & $2.264 * * *$ \\
\hline $\begin{array}{l}\text { Agriculture Is Household's Main Income Source }(1= \\
\text { Yes) }\end{array}$ & -0.656 & -0.526 & -0.777 & -0.091 & 0.048 & -0.579 & 0.165 & -0.162 \\
\hline Household Is Poor in the Village $(1=$ Yes $)$ & $-2.314 *$ & -1.440 & -1.336 & 0.006 & -0.165 & -1.024 & -0.572 & -1.007 \\
\hline Household Is Rich in the Village $(1=$ Yes $)$ & 2.037 & 1.257 & 0.812 & 0.944 & 1.301 & -0.113 & -0.134 & -0.088 \\
\hline $\begin{array}{l}\text { Household Members Worked Before in Afforestation } \\
\qquad(1=\text { Yes })\end{array}$ & 14.261 & 7.780 & 12.955 & $38.815 * *$ & $40.122 * *$ & 12.676 & $27.401 *$ & $24.070 *$ \\
\hline Household Has Cropland $>25$ Degrees $(1=$ Yes $)$ & $3.783 * * *$ & $3.023 * *$ & $3.812 * *$ & -0.430 & -0.424 & $4.097 * *$ & 0.171 & 0.011 \\
\hline Ethnic Minority? $(1=$ Yes $)$ & $-7.414 * * *$ & $-7.400 * * *$ & $-8.518 * * *$ & -0.809 & -0.880 & $-8.174 * * *$ & -2.271 & -3.038 \\
\hline
\end{tabular}


Table 4. Cont.

\begin{tabular}{|c|c|c|c|c|c|c|c|c|}
\hline \multirow{4}{*}{ Variable } & \multicolumn{8}{|c|}{ Effect on Survival Rate $(\%)^{+}$} \\
\hline & \multirow{2}{*}{\multicolumn{2}{|c|}{$\begin{array}{c}\text { Only Household- Level } \\
(n=2635)\end{array}$}} & \multicolumn{6}{|c|}{ Conditioning on Local Characteristics, Calculated as Averages at .... } \\
\hline & & & \multicolumn{3}{|c|}{$\ldots$ Village-Level $(n=1675)$} & \multicolumn{3}{|c|}{...Township-Level $(n=1785)$} \\
\hline & (1) & (2) & (3) & (4) & (5) & (6) & (7) & (8) \\
\hline \multicolumn{9}{|c|}{ Household-Level: Program Implementation } \\
\hline Years in CCFP & $4.948 * *$ & 3.311 & $6.371 * *$ & $7.581 * * *$ & $8.393 * * *$ & $5.599 * *$ & $4.455 * *$ & 3.996 \\
\hline$\times$ Worked Before in Afforestation & -4.871 & -2.887 & -4.457 & $-11.347 * *$ & $-12.056 * *$ & -4.468 & $-8.078 *$ & $-7.529 *$ \\
\hline$(\text { Years in CCFP })^{2}$ & $-0.386 * *$ & $-0.260 *$ & $-0.605 * * *$ & $-0.697 * * *$ & $-0.692 * * *$ & $-0.541 * * *$ & $-0.454 * *$ & $-0.367 *$ \\
\hline $\mathrm{x}$ Worked Before in Afforestation & $0.492 *$ & 0.347 & 0.466 & $0.848 * * *$ & $0.915 * * *$ & 0.464 & $0.638 * *$ & $0.628 * *$ \\
\hline $\begin{array}{l}\text { Household CCFP Land Has Been Inspected Before } \\
(1=\text { Yes })\end{array}$ & & 0.500 & -8.483 & $-11.723 *$ & & -9.685 & $-13.975 * *$ & \\
\hline $\mathrm{x}$ Years in CCFP & & 0.536 & 1.972 & $1.802 *$ & & 2.125 & $2.259 * *$ & \\
\hline $\begin{array}{l}\text { Household CCFP Land is formally registered } \\
\text { agricultural land }\end{array}$ & & $8.757 *$ & 4.754 & 6.941 & & 5.423 & $9.893 *$ & \\
\hline $\mathrm{x}$ Years in CCFP & & -0.875 & -0.481 & -0.702 & & -0.578 & -1.178 & \\
\hline $\begin{array}{l}\text { Household Has Other CCFP Afforestation } \\
\text { Responsibilities }\end{array}$ & & -1.429 & -1.271 & -0.590 & & -1.899 & -1.287 & \\
\hline Household "Probably/Partially Understands" the Policy & & -1.563 & -0.988 & $-1.693 *$ & $-\mathbf{2 . 0 9 4} * *$ & -0.776 & $-1.726 *$ & $-2.385 * *$ \\
\hline Household "Does not Understand" the Policy & & $-4.322 *$ & $-5.575 *$ & $-4.825 * *$ & $-5.416 * * *$ & $-4.726 *$ & $-3.928 * *$ & $-4.588 * *$ \\
\hline $\begin{array}{l}\text { Household "Knows" Their Responsibilities under } \\
\text { CCFP }\end{array}$ & & 0.781 & -3.586 & 1.801 & & -2.649 & $2.828 *$ & \\
\hline Household Receives Subsidies in Cash & & $7.342 *$ & 6.642 & -0.565 & & 5.277 & 1.210 & \\
\hline Household Receives Subsidies via Smart Card & & $6.842 * *$ & 6.031 & $7.366 *$ & & 4.833 & $7.766 * *$ & \\
\hline $\begin{array}{l}\text { CCFP Land Management. Type Is "Large HH" or } \\
\text { "Large HH and Company" }\end{array}$ & & -1.929 & -5.675 & -6.052 & & -6.028 & $-6.235 *$ & \\
\hline Orchard Trees $(1=$ Yes $)$ & -1.395 & -1.853 & -2.804 & -2.803 & -2.615 & -2.539 & -1.962 & -1.794 \\
\hline Joint Type of Tree (e.g., Bamboo) $(1=$ Yes $)$ & 1.949 & 2.031 & -1.886 & -2.115 & -2.377 & -1.215 & -1.540 & -1.847 \\
\hline
\end{tabular}


Table 4. Cont.

\begin{tabular}{|c|c|c|c|c|c|c|c|c|}
\hline Shrubs $(1=$ Yes $)$ & 1.441 & 0.845 & 0.535 & 3.075 & 2.942 & 0.985 & 3.411 & 3.291 \\
\hline Had to change tree types on CCFP land? $(1=$ Yes $)$ & -7.687 & -6.147 & 1.125 & -0.556 & -2.954 & 0.848 & -2.718 & -6.313 \\
\hline $\mathrm{x}$ Years in CCFP & 0.269 & 0.177 & -0.251 & -0.187 & 0.068 & -0.240 & 0.048 & 0.458 \\
\hline CCFP Land Main Type Is Sloped $(1=$ Yes $)$ & 0.780 & -0.876 & -1.454 & -1.998 & -2.418 & -1.557 & -1.557 & -1.842 \\
\hline CCFP Land Main Type Is Desertified $(1=$ Yes $)$ & -1.786 & -1.349 & 0.308 & 0.096 & 0.337 & 0.694 & 2.052 & 2.459 \\
\hline CCFP Plots Average Distance from Home (kilometers) & $-1.278 * * *$ & $-1.206 * * *$ & $-1.075 * * *$ & $-0.989 * * *$ & $-1.071 * * *$ & $-1.093 * * *$ & $-0.986 * * *$ & $-1.084 * * *$ \\
\hline CCFP Land was Hit by Disaster $(1=$ Yes $)$ & -2.500 & -2.056 & 0.521 & -0.148 & -0.405 & -0.190 & -1.233 & -1.412 \\
\hline Intercropping on CCFP Land $(1=$ Yes $)$ & -0.734 & -0.345 & -2.926 & -0.945 & -0.957 & -2.233 & -0.535 & -0.651 \\
\hline HH Per Capita CCFP Land Area (ha) & $7.486 * * *$ & $5.590 * *$ & 9.990 & 10.240 & 9.733 & 7.420 & 6.039 & 5.642 \\
\hline Average Yield of CCFP Land was High, Pre-CCFP & -2.162 & -3.011 & -3.207 & -1.047 & -1.240 & -2.960 & -0.694 & -1.152 \\
\hline \multicolumn{9}{|c|}{ Household-Level: Other Policies with Potential Impacts } \\
\hline HH Forest Land Is Collectively Managed & & $5.581 * * *$ & $6.073 * *$ & $4.079 * *$ & 2.468 & $6.229 * * *$ & $5.194 * *$ & $3.841 *$ \\
\hline $\begin{array}{l}\text { Received Forest Certification (as part of collective fores } \\
\text { reforms) }\end{array}$ & ector & 1.841 & 1.645 & 2.366 & 2.438 & 2.049 & 2.731 & 2.551 \\
\hline \multicolumn{9}{|c|}{ Local Economic and Institutional Characteristics (Village/Township Averages) ${ }^{++}$} \\
\hline Share of Households with CCFP Land Inspected & & & & $0.155 * * *$ & $0.195 * * *$ & & $0.135 * *$ & $0.174 * * *$ \\
\hline Share of Household CCFP Land "In the Books" & & & & -0.007 & 0.012 & & 0.009 & 0.020 \\
\hline Share of Households with Intercropping on CCFP Land & & & & -0.061 & -0.056 & & -0.063 & -0.065 \\
\hline Share of Households That "Understand" the Policy & & & & -0.013 & -0.022 & & -0.022 & -0.031 \\
\hline Share of Households That "Do not Understand" the Poli & & & & -0.077 & -0.076 & & -0.074 & -0.061 \\
\hline Share of Households That "Know Their Responsibilities & under CCFP & & & $-0.186 * * *$ & $-0.141 * *$ & & $-0.209 * * *$ & $-0.137 * *$ \\
\hline Share of Households with Other CCFP Afforestation Re & onsibilities & & & -0.025 & -0.030 & & -0.013 & -0.024 \\
\hline Subsidies Are Publically Shown in the Village or Town & & & & 0.007 & 0.006 & & 0.022 & 0.022 \\
\hline Share of Households That Received Full Subsidies & & & & $-0.079 * *$ & $-0.074 *$ & & $-0.093 * * *$ & $-0.082 * *$ \\
\hline Most Households Receive Subsidies in Cash & & & & $0.104 * *$ & 0.045 & & $0.087 *$ & 0.047 \\
\hline Number of Years Village or Township has Been Implen & nting CCFP & & & 0.554 & 0.437 & & 0.205 & 0.051 \\
\hline
\end{tabular}


Table 4. Cont.

\begin{tabular}{|c|c|c|c|c|c|c|c|}
\hline \multicolumn{3}{|c|}{ Village/Township Has Newly Developed Wasteland on Sloped Land $(1=\text { Yes })^{+++}$} & $4.443 *$ & 4.338 & & $6.140 * *$ & $6.048 * *$ \\
\hline \multicolumn{3}{|l|}{ Village/Township Has Extended Cropland in Forest Area $(1=\text { Yes })^{+++}$} & 1.154 & 1.347 & & 0.437 & 1.020 \\
\hline \multicolumn{3}{|l|}{ Village Has Fallow Land $(1=\text { Yes })^{+++}$} & -2.355 & -2.229 & & $-4.022 *$ & $-3.958 *$ \\
\hline \multicolumn{3}{|c|}{ "A Lot" of Households in the Village Participate in Rural Health Insurance $(1=\text { Yes })^{+++}$} & -4.526 & -4.674 & & -1.873 & -1.688 \\
\hline \multicolumn{3}{|l|}{ Share of Households with Forest Certificate } & -0.014 & 0.002 & & -0.012 & 0.010 \\
\hline \multicolumn{3}{|l|}{ Share of Households that Have Participated in Collective Forest Sector Reforms } & -0.005 & -0.009 & & -0.014 & -0.017 \\
\hline \multicolumn{3}{|l|}{ Share of Households that are Ethnic Minorities } & $-\mathbf{0 . 1 2 3} * * *$ & $-0.107 * * *$ & & $-\mathbf{0 . 1 0 1} * * *$ & $-0.074 * *$ \\
\hline \multicolumn{3}{|l|}{ Share of Households that Worked in Forestry Before CCFP } & 0.016 & 0.018 & & 0.006 & 0.011 \\
\hline \multicolumn{3}{|l|}{ Share of Households Utilizing Alternate Fuels } & 0.014 & 0.005 & & -0.005 & -0.013 \\
\hline \multicolumn{3}{|l|}{ Share of Households with Sloped Cropland } & $0.088 * *$ & $0.096 * * *$ & & $0.093 * * *$ & $0.102 * * *$ \\
\hline \multicolumn{3}{|l|}{ Share of Households with Collectively Managed Forestland } & 0.059 & 0.074 & & 0.059 & 0.071 \\
\hline \multicolumn{3}{|l|}{ Average Share of Household Labor that is Migrant } & $-0.001 *$ & $-0.001 *$ & & -0.001 & -0.001 \\
\hline Log-Likelihood Function & -3898.19 & -2322.40 & -2204.11 & -2230.99 & -2500.38 & -2383.05 & -2421.22 \\
\hline McFadden's Adjusted $R^{2}$ & 0.056 & 0.078 & 0.115 & 0.108 & 0.072 & 0.106 & 0.096 \\
\hline
\end{tabular}

$\ldots=$ Share of households in the village; $*$ Significant a $10 \% / * *$ Significant at $5 \% / * * *$ Significant at $1 \%$; ${ }^{+}$Coefficients can be interpreted as the increase in survival rate (\%) for an increase in one unit of the variable in question; ${ }^{++}$Village and township averages were calculated for villages/townships with data from at least 15 households per village or township; ${ }^{++}$Calculated as a discrete Yes or No based on the average response of households in the village or township. Models utilize robust standard errors clustered at the village. 
All models are estimated with robust standard errors clustered at the village level. Since the interval regression explains the underlying (unobserved) survival rate, parameter estimates are interpreted as the marginal effect of a one-unit increase of the variable in question on survival rate (e.g., a parameter estimate of 10 means that a one unit increase of the variable in question is associated with an increase in the survival rate by 10 percentage points). All household and village-share variables are scaled to a 1 to 100 range so that parameter estimates for these can be interpreted directly, as the impact of an increase in village share by $1 \%$ on survival rate.

Overall, model results broadly accord with expectations. In terms of household characteristics, households with higher levels of human capital in forestry activities appear to be better at keeping program trees alive, as would be expected; having higher per capita forest area, and a member who has worked before in afforestation, pre-CCFP, are both positively associated with survival rate in all specifications, with the former being statistically significant in all. Landholders with experience in forest management and tree planting are more likely to enthusiastically adopt re/afforestation activities than those who do not have such experience. Other work in the literature finds that poor incorporation of forest management knowledge transfer, resulting in a lack of sufficient tending and thinning, is associated with low plantation survival rates in China, while CCFP outcomes in locations that that are historically not forest areas - and therefore where local forest management experience is low-have been unsatisfactory [29]. Lack of technical support has often been noted as a key shortcoming in program implementation; such support could help reduce perception of risk and improve outcomes [30].

Though less robust, results also provide weak evidence that household capital constraints adversely affect ability to manage program-planted trees; being "rich" in the village (and therefore likely having more assets to contribute to production activities) is in general positively associated with survival rate, while being "poor" is negatively associated.

Reflecting the time costs of labor, each additional kilometer that CCFP plots are from the household's home on average is associated with a decrease in survival rates by between $0.99 \%$ and $1.28 \%$, with parameter estimates statistically significant across all specifications. Smallholders empowered to select plots for re/afforestation can often choose plots located further from their homes or roads to reduce the opportunity costs (in terms of income and food security) of retiring more accessible agricultural land [30]. Indeed, $\mathrm{Xu}$ and colleagues [10] find that when households have autonomy in whether or not to participate in CCFP, they strongly tend to choose plots farther away from the homestead. However, this comes at the cost of environmental outcomes. Bennett and colleagues [24] found that when CCFP participants are allowed to select plots for conversion, famers choose less fertile and more remote plots, with this resulting in lower survival rates [24].

Capturing labor opportunity costs, higher village or township average share of participant household labor engaged in off-farm migratory work is associated with lower survival rates at the household level, with this statistically significant in the models that include village characteristics. These results suggest that in locales where regional off-farm opportunities are more plentiful, households tend to redistribute labor effort towards these more profitable activities and away from tending program-planted trees.

In terms of the effects of local characteristics, relative endowments of land versus labor at the local level produce statistically significant results that accord with expectations, whereby having higher labor endowments per unit of land is broadly associated with higher survival rates at the household level (i.e., ostensibly due to higher availability of labor to invest in managing program-planted trees). For example, 
being in a village with fallow land - suggesting a higher land/labor ratio (though possibly also reflecting a local economy where off-farm work is more plentiful) — is associated with lower survivorship at the household level. Similarly, being in a village with newly-developed wasteland on sloping land and where a larger share of sample households still cultivates crops on sloping land - both of which reflect lower land/labor ratios, which create incentives to expand cultivated area-are associated with higher survival rates on household land.

Model results also suggest that learning-by-doing and specialization improves program outcomes. Specifically, "Years in CCFP" and "(Years in CCFP)" are both statistically significant in most specifications, with their relative signs suggesting that households improve their ability to manage trees the longer they are in the program, with this effect decreasing over time. The interactions of these variables with whether or not a household member has worked before in afforestation also indicates that households with forestry experience start out with an advantage in managing forest area, though with this decreasing over time (i.e., for household with members that have worked before in forestry, the base survival begins at $39 \%$ in the village models, with this decreasing but leveling out over time).

Management structure on household enrolled land clearly appears to influence survival rates. Higher household per capita area enrolled in CCFP is positively associated with survival rates, suggesting that household specialization in providing program-targeted ecological services improves survival rates. Conversely, if household land is managed by a contracted third party under the "Large Household" or "Large Household + Company" management types — which generally consist of a large portion or all of village CCFP land managed by a few large households or a combination of this and a contracted outside implementation unit - survival rates tend to be lower, with this effect statistically significant in one of five specifications.

Regarding ecological factors, orchard crops appear to have lower survival rates in general in comparison to timber trees (the omitted category), while shrubby tree crops have better survival rates. Planting program trees primarily on sloping land, and household CCFP land being affected by disaster (i.e., drought, flood or pest/diseases), are both associated with reduced survivorship, though these effects are not robust across specifications. Having CCFP land that is formally registered as agricultural land is positively associated with survival rate, and is statistically significant in two of five specifications. This likely captures the effect of land quality on survival rates, since formally registered agricultural land is generally of better quality (from conversations with SFA officials and observations made in the field).

Also, households who had to change the tree type initially planted on enrolled land due to low survival rates tend to have lower survival rates for currently planted trees, even when controlling for the number of years in the program (i.e., via interacting this with number of years in the program). This suggests that poor initial selection of tree species that are adapted to local conditions can delay achievement of longer-term outcomes.

Finally, of relevance for the program's ecological and economic sustainability, intercropping on enrolled land is generally associated with lower survival rates. The degree to which households are allowed to intercrop on enrolled land has specific relevance for household livelihoods, especially in land-scarce regions with low off-farm wage labor opportunities. Note, however, that this effect is similar at the village level, with share of participant households at the village-level that are intercropping also negatively associated with survival rate at the household level. This suggests that this variable could also 
be picking up local institutional effects, whereby incentives to achieve higher survival rates are weaker in locales with a less rigorous and more permissive implementation regimes.

In terms of institutional impacts, several variables appear to be strongly associated with survival rates. First, the fact that a household "does not understand" the CCFP is negatively associated with survival rates, with this statistically significant across all specifications. More intriguing, the share of households at either the village or township level that "do not understand" the CCFP policy is also negatively associated with survival rates at the household level. This suggests that the degree to which local governments systematically consult and engage with participant households and communities during program implementation has an important effect on program outcomes.

Participant households having additional afforestation responsibilities apart from afforesting cropland — which include either afforestation of "wasteland" or "closed-mountain" afforestation — tend to have lower survival rates, as do households in villages with a higher share of participant households that have these additional responsibilities. This suggests that additional program demands on household labor as part of program participation comes at the potential cost of weakening outcomes.

Finally, variables capturing the inspection regime reveal a somewhat complex picture. At the household level, direct correlation between whether CCFP land has been inspected before and survival rate on CCFP land is positive and highly statistically significant in the data set. Indeed, inspection is positive but statistically insignificant in the household-level model. However, in specifications using village (and township) characteristics, it becomes negative and statistically significant in two of five specifications, while share of sample participant households in the village (or township) whose CCFP land has been inspected is very positively associated with household-level survivorship, statistically significant in all specifications where it is included. Due to concerns about the direction of causality, the household-level inspection variable was also interacted with years in the program, which finds that each additional year that inspected CCFP land has been in the program is positively associated with survival rate, with this statistically significant in three of five specifications. Overall, this suggests that while a strong and well-functioning inspection regime at the village level is strongly associated with better survivorship, household-level effects are more complicated, likely capturing a range of different factors including informational asymmetries and complex behavioral dynamics not fully captured by the other explanatory variables in the model.

That some variables likely vary systematically by region could be potentially complicating identification of their effects, since these could be confounded with other unobserved regional impacts, including eco-regions, biome and local climate. The lack of detailed data on tree species in the survey, for example, means that each tree category likely encompasses significant heterogeneity, with the nature of this varying regionally (for example the SFA documents 72 types of ecological trees, 21 economic trees, 51 shrubs and 20 joint trees in southern China; and 42 type of ecological trees, 16 economic trees, 53 shrubs and 16 joint trees in northern China [31]). As such, to disentangle these effects and improve identification, an additional set of specifications were explored wherein a subset of variables were interacted with the regional indicators. Variables deemed likely to be confounded with regional effects were as follows: whether or not the household has sloped cropland; household per capita CCFP land area; tree type; village share of participant households that are intercropping on their CCFP land; village share of participant households that have other afforestation responsibilities as part of CCFP; whether 
or not the village has fallow land; village share of households that are ethnic minorities; and village average of household share of labor in off-farm migrant work.

Model results are presented in Tables 5 and 6 below. Interactions with the regional indicators indeed appear to disentangle some of these effects and improve overall model performance, with (11) having the best measure of fit of any of the specifications. The associated survival rate impacts of tree type indeed vary in important ways across regions. "joint type" of trees interacted with "southeast" in a positive and significant way, with large parameter estimates in all specifications, likely picking up the faster-growing bamboo plantations of the southeastern provinces ("joint type" covers tree types which overlap both "ecological" and "economic" delineations, as well as bamboo, which is considered as a special tree type in China's forestry statistics system [31]). Similarly, "shrubs" in the southwest are also associated with a large positive boost to survival rates, significant in all specifications.

Village-level characteristics all vary regionally in important ways: the impacts of village share of participant households that intercrop on CCFP land; whether or not the village has fallow land; the village share of participant households that are ethnic minorities; and the average village share of participant household labor that is migrant. The main effect of the village share of households intercropping on their CCFP land is large, negative and significant, again suggesting that a village-level implementation regime that is more permissive regarding how households utilize CCFP land might result in reduced effectiveness in achieving targeted survival rate targets. However, this appears to be offset by significant regional impacts for the northwest and southwest. Whether the village has fallow land also retains its negative impact in the main effect, but for the southwest has a net positive impact on survival rates, suggesting that factors other than village land/labor ratio could be driving this relationship.

The strong and statistically significant negative effect of village share of participant households that are ethnic minorities disappears when the village variable is interacted with regional indicators. This confirms the suspicion that this variable could be picking up important unobserved regional characteristics that have a bearing on the effectiveness of program implementation, such as remoteness (e.g., from regional government seat, or regional markets) or distinct differences in local customary governance structures for forestry and agriculture. In particular, interactions between the village share of participant households that are ethnic minorities and the regional indicators of southwest and northwest produce highly significant and negative parameter estimates, while the main effect becomes positive and statistically insignificant, and whether the household is an ethnic minority also becomes statistically insignificant from being previously highly statistically significant with negative impacts in the earlier models.

Interestingly, the regional interactions with the ethnic minority share could also be capturing important social dimensions or indigenous knowledge. It has been found (unsurprisingly) that a farmer's ethnic group influences perceptions regarding tree planting [32]. Approaches to silviculture also can vary among ethnic groups based on the length of time in a given area and on experience planting specific species or combinations thereof. In southwestern China, different communities employ different rotation and fallow periods, as well as intercropping of tree species to avoid declines in productivity that have been associated with monocultures employed in state forestry programs and by ethnic Han groups with a shorter history in the area [30]. 
Table 5. Interval regression model of tree survivorship on household conversion of cropland to forests program (CCFP) enrolled land with regional interactions.

\begin{tabular}{|c|c|c|c|c|}
\hline \multirow[t]{2}{*}{ Variable } & \multicolumn{4}{|c|}{$\begin{array}{l}\text { Household Only } \\
\text { (9) } \\
\text { Interactions with regional indicators }\end{array}$} \\
\hline & Direct Effect (\%) ${ }^{+}$ & \multirow{2}{*}{$\frac{\text { Northwest }^{+}}{-2.699}$} & \multirow{2}{*}{$\begin{array}{c}\text { Southwest }^{+} \\
-6.499 * *\end{array}$} & \multirow{2}{*}{$\frac{\text { Southeast }^{+}}{-2.285}$} \\
\hline Constant/Regional Dummies & $64.668 * * *$ & & & \\
\hline \multicolumn{5}{|c|}{ Household Socioeconomic Characteristics } \\
\hline Household Labor Population (>15 Years Old) & 0.532 & & & \\
\hline Respondent Has High school or Above Education ( 1 = Yes $)$ & -0.479 & & & \\
\hline Respondent Has No Education or “Other” (1 = Yes) & 0.817 & & & \\
\hline Share of Household Labor That is "Migrant" & -0.013 & & & \\
\hline HH PC Crop Area Pre-CCFP (ha) & -2.26 & & & \\
\hline HH PC Forest Area Pre-CCFP (ha) & $2.318 * * *$ & & & \\
\hline Agriculture Is HH's Main Income Source ( 1 = Yes) & -0.032 & & & \\
\hline HH Is Poor in the Village $(1=$ Yes $)$ & -1.2 & & & \\
\hline HH Is Rich in the Village ( $1=$ Yes $)$ & 1.38 & & & \\
\hline HH Members Worked Before in Afforestation ( 1 = Yes) & 8.102 & & & \\
\hline HH Has cropland $>25$ Degrees $(1=$ Yes $)$ & $3.351 * *$ & 2.09 & -0.765 & -3.448 \\
\hline Ethnic Minority? $(1$ = Yes $)$ & $-7.583 * * *$ & & & \\
\hline \multicolumn{5}{|c|}{ Household-Level: Program Implementation } \\
\hline Years in CCFP & $3.708 *$ & & & \\
\hline$\times$ Worked Before in Afforestation & -2.87 & & & \\
\hline$(\text { Years in CCFP })^{2}$ & $-0.298 *$ & & & \\
\hline$\times$ Worked before in Afforestation & 0.332 & & & \\
\hline HH CCFP Land Has Been Inspected Before $(1=$ Yes $)$ & -0.734 & & & \\
\hline$\times$ Years in CCFP & 0.688 & & & \\
\hline Household CCFP Land Is "In the Books" & 7.284 & & & \\
\hline$\times$ Years in CCFP & -0.65 & & & \\
\hline
\end{tabular}


Table 5. Cont.

\begin{tabular}{|c|c|c|c|c|}
\hline \multirow[t]{2}{*}{ Variable } & \multirow{2}{*}{ Direct Effect (\%) $)^{+}$} & $\begin{array}{r}\text { Househo } \\
(9 \\
\text { Interact }\end{array}$ & $\begin{array}{l}\text { nly } \\
\text { with regional }\end{array}$ & icators \\
\hline & & Northwest $^{+}$ & Southwest $^{+}$ & Southeast $^{+}$ \\
\hline \multicolumn{5}{|c|}{ Household-Level: Program Implementation } \\
\hline HH Has Other CCFP Afforestation Responsibilities & -1.849 & & & \\
\hline Household "Probably/Partially Understands" the Policy & $-2.004 *$ & & & \\
\hline Household "Does not Understand" the Policy & $-4.382 * *$ & & & \\
\hline Household "Knows" Their Responsibilities under CCFP & 0.672 & & & \\
\hline Household Receives Subsidies in Cash & $6.815 *$ & & & \\
\hline Household Receives Subsidies via Smart Card & $6.535 * *$ & & & \\
\hline CCFP Land Management Type Is "Large HH" or "Large HH \& Company" & -2.639 & & & \\
\hline Orchard Trees $(1=$ Yes $)$ & $-4.481 * *$ & -0.448 & 5.376 & $8.948 *$ \\
\hline Joint Type of Tree (e.g., Bamboo) $(1=$ Yes $)$ & -5.948 & 5.603 & $13.025 * * *$ & $14.976 * * *$ \\
\hline Shrubs $(1=$ Yes $)$ & -6.077 & 2.061 & $15.595 * * *$ & $11.668 * *$ \\
\hline Had to Change Trees Types on CCFP Land? $(1=$ Yes $)$ & -7.021 & & & \\
\hline$\times$ Years in CCFP & 0.335 & & & \\
\hline CCFP Land Main Type Is Sloped ( 1 = Yes) & -0.477 & & & \\
\hline CCFP Land Main Type Is Desertified ( $1=$ Yes) & -1.303 & & & \\
\hline CCFP Plots Average Distance from Home & $-1.17 * * *$ & & & \\
\hline CCFP Land Was Hit by Disaster $(1=$ Yes $)$ & -2.017 & & & \\
\hline Intercropping on CCFP Land ( 1 = Yes) & -0.162 & & & \\
\hline HH Per Capita CCFP Land Area (ha) & $8.103 * *$ & -9.532 & -8.3 & 0.509 \\
\hline Average Yield of CCFP Land Was High, Pre-CCFP & -3.027 & & & \\
\hline \multicolumn{5}{|l|}{ Household-Level: Other Policies with Potential Impacts } \\
\hline HH Forest Land is Collectively Managed & $5.346 * * *$ & & & \\
\hline Received Forest Certification (as part of collective forest sector reforms) & 1.764 & & & \\
\hline Log-Likelihood Function & \multicolumn{4}{|c|}{-3866.428} \\
\hline McFadden's Adjusted $R^{2}$ & \multicolumn{4}{|c|}{0.058} \\
\hline
\end{tabular}


* Significant a $10 \% / * *$ Significant at $5 \% / * * *$ Significant at $1 \%$; ${ }^{+}$Coefficients can be interpreted as the increase in survival rate $(\%)$ for an increase in one unit of the variable in question; interaction term coefficients should be added to the direct effect to calculate the total effect for each regional subsample; Models utilize robust standard errors clustered at the village.

Table 6. Interval regression model of tree survivorship on household conversion of cropland to forests program (CCFP) enrolled land with regional interactions.

\begin{tabular}{|c|c|c|c|c|c|c|c|c|}
\hline \multirow{4}{*}{ Variable } & \multicolumn{8}{|c|}{ Local Variables at the Village-Level } \\
\hline & \multicolumn{4}{|c|}{ (10) } & \multicolumn{4}{|c|}{ (11) } \\
\hline & \multirow{2}{*}{$\begin{array}{c}\text { Direct } \\
{\text { Effect }(\%)^{+}}^{+}\end{array}$} & \multicolumn{3}{|c|}{ Interactions with regional indicators } & \multirow{2}{*}{$\begin{array}{c}\text { Direct } \\
\text { Effect }(\%)^{+}\end{array}$} & \multicolumn{3}{|c|}{ Interactions with regional indicators } \\
\hline & & Northwest $^{+}$ & Southwest $^{+}$ & Southeast $^{+}$ & & Northwest $^{+}$ & Southwest $^{+}$ & Southeast $^{+}$ \\
\hline Constant/Regional Dummies & $\mathbf{5 7 . 8 2 8} * * *$ & $20.359 * * *$ & 8.468 * & -11.161 & $63.096 * * *$ & $23.579 * * *$ & $13.315 * *$ & -10.283 \\
\hline \multicolumn{9}{|c|}{ Household Socioeconomic Characteristics } \\
\hline Household Labor Population (>15 Years Old) & 0.115 & & & & 0.189 & & & \\
\hline $\begin{array}{l}\text { Respondent Has High school or Above Education } \\
(1=\text { Yes })\end{array}$ & 0.146 & & & & 0.364 & & & \\
\hline Respondent Has No Education or "Other" ( 1 = Yes) & -0.013 & & & & -0.380 & & & \\
\hline Share of Household Labor that Is "Migrant" & 0.018 & & & & 0.016 & & & \\
\hline HH PC Crop Area Pre-CCFP (ha) & -2.520 & & & & -4.442 & & & \\
\hline HH PC Forest Area Pre-CCFP (ha) & $2.051 *$ & & & & $2.246 *$ & & & \\
\hline Agriculture is HH's Main Income Source $(1=$ Yes $)$ & -0.451 & & & & -0.311 & & & \\
\hline HH Is Poor in the Village $(1=$ Yes $)$ & -0.323 & & & & -0.777 & & & \\
\hline HH Is Rich in the Village ( $1=$ Yes) & 1.256 & & & & 0.979 & & & \\
\hline HH Members Worked Before in Afforestation $(1=$ Yes $)$ & $46.610 * * *$ & & & & $36.636 * *$ & & & \\
\hline HH Has Cropland > 25 Degrees ( $1=$ Yes $)$ & 1.669 & -2.624 & -3.631 & -4.329 & 2.113 & -2.963 & -4.965 & -3.781 \\
\hline Ethnic Minority? $(1=$ Yes $)$ & -0.731 & & & & -0.730 & & & \\
\hline \multicolumn{9}{|c|}{ Household-Level: Program Implementation } \\
\hline Years in CCFP & $7.582 * * *$ & & & & $6.477^{* *}$ & & & \\
\hline$\times$ Worked Before in Afforestation & $-13.630 * * *$ & & & & $-10.577 * *$ & & & \\
\hline$(\text { Years in CCFP })^{2}$ & $-0.690 * * *$ & & & & $-0.583 * * *$ & & & \\
\hline$\times$ Worked Before in Afforestation & $0.974 * * *$ & & & & $0.754 * * *$ & & & \\
\hline HH CCFP Land Has Been Inspected Before ( $1=$ Yes $)$ & -8.653 & & & & -8.267 & & & \\
\hline
\end{tabular}


Table 6. Cont

\begin{tabular}{|c|c|c|c|c|c|c|c|c|}
\hline \multirow{4}{*}{ Variable } & \multicolumn{8}{|c|}{ Local Variables at the Village-Level } \\
\hline & \multicolumn{4}{|c|}{ (10) } & \multicolumn{4}{|c|}{ (11) } \\
\hline & \multirow{2}{*}{$\begin{array}{c}\text { Direct } \\
\text { Effect }(\%)^{+}\end{array}$} & \multicolumn{3}{|c|}{ Interactions with regional indicators } & \multirow{2}{*}{$\begin{array}{c}\text { Direct } \\
\text { Effect }(\%)^{+}\end{array}$} & \multicolumn{3}{|c|}{ Interactions with regional indicators } \\
\hline & & Northwest $^{+}$ & Southwest $^{+}$ & Southeast $^{+}$ & & Northwest $^{+}$ & Southwest $^{+}$ & Southeast $^{+}$ \\
\hline$\times$ Years in CCFP & 1.263 & & & & 1.205 & & & \\
\hline Household CCFP Land is Registered Agric. Land & 4.287 & & & & 7.776 & & & \\
\hline $\mathrm{x}$ Years in CCFP & -0.336 & & & & -0.817 & & & \\
\hline HH Has Other CCFP Afforestation Responsibilities & -0.552 & & & & -0.396 & & & \\
\hline $\begin{array}{l}\text { Household "Probably/Partially Understands" the } \\
\text { Policy }\end{array}$ & -1.634 & & & & -1.470 & & & \\
\hline Household "Does not Understand" the Policy & $-4.975 * * *$ & & & & $-4.708 * *$ & & & \\
\hline $\begin{array}{l}\text { Household "Knows" Their Responsibilities under } \\
\text { CCFP }\end{array}$ & 2.030 & & & & 2.081 & & & \\
\hline Household Receives Subsidies in Cash & 1.176 & & & & 1.451 & & & \\
\hline Household Receives Subsidies via Smart Card & $7.274 * *$ & & & & $6.699 *$ & & & \\
\hline $\begin{array}{l}\text { CCFP Land Management Type is "Large HH" or } \\
\text { "Large HH and Company" }\end{array}$ & $-5.564 *$ & & & & -5.204 & & & \\
\hline Orchard Trees $(1=$ Yes $)$ & 0.842 & $-11.689 * *$ & -5.638 & 4.168 & 3.274 & $-16.046 * * *$ & $-7.391 *$ & 0.541 \\
\hline Joint Type of Tree (e.g., Bamboo) $(1=$ Yes $)$ & $-6.061 *$ & 1.730 & 1.968 & $18.134 * *$ & -3.078 & -4.785 & -0.667 & $13.458 * *$ \\
\hline Shrubs $(1=$ Yes $)$ & $-11.697 * *$ & 7.667 & $16.181 * * *$ & 7.605 & $-13.266 * *$ & 5.213 & $20.284 * * *$ & 13.231 \\
\hline Had to change trees types on CCFP land? $(1=$ Yes $)$ & -2.690 & & & & -0.744 & & & \\
\hline$\times$ Years in CCFP & -0.061 & & & & -0.274 & & & \\
\hline CCFP Land Main Type is Sloped ( $1=$ Yes $)$ & -1.674 & & & & -1.578 & & & \\
\hline CCFP Land Main Type is Desertified ( $1=$ Yes) & 0.249 & & & & 0.238 & & & \\
\hline CCFP Plots Average Distance from Home & $-0.539 *$ & & & & $-0.677 * *$ & & & \\
\hline CCFP Land was Hit By Disaster (1 = Yes) & 0.455 & & & & 0.203 & & & \\
\hline Intercropping on CCFP Land $(1=$ Yes $)$ & -0.583 & & & & -0.450 & & & \\
\hline HH Per Capita CCFP Land Area (ha) & 9.602 & -3.117 & -8.724 & -10.167 & 7.874 & 0.767 & -2.055 & -2.668 \\
\hline Average Yield of CCFP Land was High, Pre-CCFP & -0.786 & & & & -0.149 & & & \\
\hline
\end{tabular}


Table 6. Cont

\begin{tabular}{|c|c|c|c|c|c|c|c|c|}
\hline \multirow{4}{*}{ Variable } & \multicolumn{8}{|c|}{ Local Variables at Village-Level } \\
\hline & \multirow{3}{*}{$\begin{array}{c}\text { Direct } \\
\text { Effect (\%) }{ }^{+}\end{array}$} & \multicolumn{3}{|c|}{ (10) } & \multicolumn{4}{|c|}{ (11) } \\
\hline & & \multicolumn{3}{|c|}{ Interactions with regional indicators } & \multirow{2}{*}{$\begin{array}{c}\text { Direct } \\
\text { Effect (\%) }\end{array}$} & \multicolumn{3}{|c|}{ Interactions with regional indicators } \\
\hline & & Northwest $^{+}$ & Southwest $^{+}$ & Southeast $^{+}$ & & Northwest $^{+}$ & Southwest $^{+}$ & Southeast $^{+}$ \\
\hline \multicolumn{9}{|c|}{ Household-Level: Other Policies with Potential Impacts } \\
\hline HH Forest Land is Collectively Managed & $4.544 * *$ & & & & 4.486 ** & & & \\
\hline Received Forest Certification & 2.370 & & & & 2.081 & & & \\
\hline Share of Households with CCFP Land Inspected & $0.187 * * *$ & & & & $0.206 * * *$ & & & \\
\hline Share of Household CCFP Land "In the Books" & 0.005 & & & & 0.013 & & & \\
\hline $\begin{array}{l}\text { Share of Households with Intercropping on CCFP } \\
\text { Land }\end{array}$ & $-0.131 * *$ & & & & $-\mathbf{0 . 2 8 8} * * *$ & $0.319 * * *$ & 0.250 ** & $0.424 * * *$ \\
\hline Share of Households That "Understand" the Policy & -0.003 & & & & 0.039 & & & \\
\hline $\begin{array}{l}\text { Share of Households That "Don't Understand" the } \\
\text { Policy }\end{array}$ & -0.002 & & & & -0.016 & & & \\
\hline $\begin{array}{l}\text { Share of Households That } \\
\text { "Know Their Responsibilities" under CCFP }\end{array}$ & $-0.148 * * *$ & & & & $-0.146 * * *$ & & & \\
\hline $\begin{array}{l}\text { Share of Households with Other CCFP Afforestation } \\
\text { Responsibilities }\end{array}$ & -0.045 & & & & $0.177^{* *}$ & $-0.254 * * *$ & $-0.294 * * *$ & $-0.168 * * *$ \\
\hline $\begin{array}{l}\text { Subsidies Are Publically Shown in the Village or } \\
\text { Township }\end{array}$ & 0.027 & & & & 0.011 & & & \\
\hline Share of Households that Received Full Subsidies & $-0.086 * *$ & & & & $-0.085 * * *$ & & & \\
\hline Share of Households that Received Subsidies in Cash & $0.086 * *$ & & & & $0.086 *$ & & & \\
\hline $\begin{array}{l}\text { Number of Years Village Has Been Implementing } \\
\text { CCFP }\end{array}$ & 0.475 & & & & 0.109 & & & \\
\hline $\begin{array}{l}\text { Village Has Newly Developed Wasteland on Sloped } \\
\text { Land }(1=\text { Yes })^{+++}\end{array}$ & 2.325 & & & & 0.012 & & & \\
\hline $\begin{array}{l}\text { Village Has Extended Cropland in Forest Area } \\
(1=\text { Yes })^{++}\end{array}$ & -1.897 & & & & 0.052 & & & \\
\hline Village Has Fallow Land $(1=\text { Yes })^{+++}$ & -2.146 & -10.988 & 6.172 & $-12.990 * *$ & $-7.191 *$ & -3.915 & $10.528 * *$ & -7.581 \\
\hline $\begin{array}{l}\text { "A Lot" of HHs in the Village Enrolled in Rural } \\
\text { Health Insurance }\end{array}$ & -4.950 & & & & $-8.459 *$ & & & \\
\hline Share of Households with Forest Certificate & -0.003 & & & & 0.015 & & & \\
\hline
\end{tabular}


Table 6. Cont.

\begin{tabular}{|c|c|c|c|c|c|c|c|c|}
\hline \multirow{4}{*}{ Variable } & \multicolumn{8}{|c|}{ Local Variables at the Village-Level } \\
\hline & \multicolumn{4}{|c|}{ (10) } & \multicolumn{4}{|c|}{ (11) } \\
\hline & \multirow{2}{*}{$\begin{array}{c}\text { Direct } \\
{\text { Effect }(\%)^{+}}^{+}\end{array}$} & \multicolumn{3}{|c|}{ Interactions with regional indicators } & \multirow{2}{*}{$\begin{array}{c}\text { Direct } \\
\text { Effect }(\%)^{+}\end{array}$} & \multicolumn{3}{|c|}{ Interactions with regional indicators } \\
\hline & & Northwest $^{+}$ & Southwest $^{+}$ & Southeast $^{+}$ & & Northwest $^{+}$ & Southwest $^{+}$ & Southeast $^{+}$ \\
\hline \multicolumn{9}{|c|}{ Household-Level: Other Policies with Potential Impacts } \\
\hline $\begin{array}{l}\text { Share of Households That Have Participated in } \\
\text { Collective Reform }\end{array}$ & -0.019 & & & & -0.040 & & & \\
\hline Share of Households That Are Ethnic Minorities & -0.002 & $-0.267 * *$ & $-0.123 *$ & 0.072 & 0.001 & $-0.190 *$ & $-0.141 * *$ & -0.098 \\
\hline $\begin{array}{l}\text { Share of Households That Worked in Forestry Before } \\
\text { CCFP }\end{array}$ & 0.030 & & & & -0.031 & & & \\
\hline Share of Households Utilizing Alternate Fuels & 0.032 & & & & 0.052 & & & \\
\hline Share of Households with Sloped Cropland & $0.095 * * *$ & & & & $0.081 * * *$ & & & \\
\hline $\begin{array}{l}\text { Share of Households with Collectively Managed } \\
\text { Forestland }\end{array}$ & -0.008 & & & & -0.022 & & & \\
\hline Average Share of Household Labor That Is Migrant & 0.000 & -0.002 & -0.002 & 0.004 & 0.001 & -0.003 & -0.003 & 0.002 \\
\hline Log-Likelihood Function & \multicolumn{4}{|c|}{-2105.72} & \multicolumn{4}{|c|}{-2071.63} \\
\hline McFadden's Adjusted $R^{2}$ & \multicolumn{4}{|c|}{0.138} & \multicolumn{4}{|c|}{0.146} \\
\hline
\end{tabular}

* Significant a $10 \% / * *$ Significant at $5 \% / * * *$ Significant at $1 \% ;{ }^{+}$Coefficients can be interpreted as the increase in survival rate $(\%)$ for an increase in one unit of the variable in question. Interaction term coefficients should be added to the direct effect to calculate the total effect for each regional subsample; ${ }^{++}$Village and township averages were calculated for villages/townships with data from at least 15 households per village or township; ${ }^{++}$Calculated as a discrete Yes or No based on the average response of households in the village or township. Models utilize robust standard errors clustered at the village. 


\section{Conclusions}

The CCFP is representative of China's ongoing transition from an extractive economic growth model to one that is more environmentally sustainable. This accords with international trends, which have seen a net increase in forest cover occurring in several Asian countries in recent decades-most notably in China, Vietnam, Bhutan and India — in what has been termed a "forest transition" [33-36]. While urbanization and de-agrarianization have been identified as major causes of forest transition elsewhere (and particularly in developed/western countries), in Asia, government programs promoting timber production and provision of ecosystems services have been a major driver of the increase in land designated as forest $[34,37]$.

It is important to improve the understanding of which program design elements are most effective for ensuring that such programs successfully achieve their re/afforestation outcomes, and are able to sustainably facilitate such a transition in Asia and elsewhere. This is especially important in the presence of heterogeneity in local institutional and socioeconomic conditions. As the world's largest re/afforestation Payment for Ecosystem Services program, encompassing a wide array of ecological and socioeconomic conditions, the CCFP provides an excellent opportunity to do this.

In general, our analysis provides evidence that household and local socioeconomic characteristics, as well as local program implementation regime, all play important roles in determining outcomes. At the household level, households with pre-existing training and experience in forestry, as well as higher labor endowments relative to land, do better at managing trees. Time in the program also appears to increase tree survivorship, suggesting that important learning-by-doing effects are taking place as well. Conversely, higher opportunity costs for either land or labor have the opposite effect. Related to this, households in areas with relatively abundant labor (i.e., high labor/land ratios), and with relatively poor access to off-farm work opportunities, in general do better at keeping their trees alive, likely due to having more labor to invest in planting and management. This suggests that providing ongoing technical support and training to households to help them improve their forestry skills could have important knock-on effects on program ecological outcomes. These findings accord with prior findings of Bennett and colleagues [24].

Our findings also provide some strong evidence that the local implementation regime has an important effect on outcomes, and that both incentives and monitoring are critical. First, the most important of these results is that the degree to which program managers have consulted with participant communities and households has a strong positive influence on outcomes. This is captured in the degree to which households indicate that they do not understand the program, and for those who are in villages where a large share of participant households also indicate that they do not understand the program, both which result in households achieving lower survival rate outcomes. In general, this finding resonates with accepted best practice for Payments for Ecosystem Services programs, which stresses that ongoing consultation with communities during all stages of program development and implementation will help to both improve outcomes and reduce costs.

Another important result is that in places where intercropping on enrolled land is more predominant, households are less successful at keeping program trees alive. While more work needs to be done to understand the specifics of this relationship, these results suggest that tradeoffs exist between how rural livelihoods issues are addressed and program environmental goals; allowing households to intercrop on 
CCFP enrolled land might help to minimize impacts on food and cash crop production, but at the expense of tree survivorship. It is also possible that these results reflect the technical challenges evident in engendering effective and sustainable agroforestry regimes. Viewed from a different angle, however, it is also possible that this could be capturing the adverse impacts on survivorship of more permissive, less rigorous implementation regimes.

Finally, a number of intriguing results suggest that improvements could be made to the program's subsidy and inspection regime. In particular, the village share of households with CCFP land that has been inspected has a strong positive relationship on household-level tree survivorship, while whether or not a household's CCFP land has been inspected has a strong negative one. This suggests that a well-managed local inspection regime clearly does better at achieving outcomes. However, ongoing monitoring and inspections might be required to ensure that program goals are sustainably met, possibly due to the fact post-inspection, households face weaker incentives to continue maintaining survival rates. Similarly, the strong negative relationship between household-level survivorship and the share of households in a village that have received full subsidies also suggests that once the program winds down in a particular locale, thus reducing local government program implementation efforts, households will at the very least begin to curtail efforts at managing program-planted trees. This suggests that some degree of ongoing subsidy support and monitoring will be needed for CCFP forestry outcomes to be sustainably maintained and eventually consolidated, though the degree to which this is the case likely varies significantly by locale.

Admittedly, caution should be exercised when using the results of this analysis to make larger inferences regarding the CCFP's success in incentivizing household delivery of targeted forest ecosystem benefits, especially for off-site benefits. Forests provide a complex array of ecological services, with tree survivorship alone falling far short of capturing the spatial and temporal complexity of the underlying processes. Indeed, Le and colleagues argue that reforestation assessments should not be based on success indicators alone, but should incorporate the drivers of success, which encompass an array of biophysical, socioeconomic, institutional and project characteristics [22]. Ongoing monitoring and evaluation work for the CCFP should thus broaden its portfolio of indicators, especially regarding targeted ecological outcomes. This is particularly important given observations that China's afforestation statistics could be hiding a significant degree of exotic tree species planting, which could be having adverse impacts on biodiversity habitat [38].

The nature of the dependent variables used for this analysis, combined with the lack of detailed information on tree species planted and other important biophysical indicators (e.g., location within watersheds, soil type, microclimate, etc.), also limit the ability of this data set to capture on-site environmental outcomes. Lack of counterfactuals or detailed measures of ex ante household socioeconomic characteristics also limit the ability to rigorously identify program environmental impacts at the household level.

The results of this analysis are nonetheless revealing and valuable. They are based on what is arguably one of the largest and most representative samples yet available for evaluating the CCFP; other work has generally relied on much smaller, more regionally restricted survey data sets e.g., [10,11,15]. Model results, furthermore, suggest that real relationships are being uncovered; several parameter estimates are found to be robust across specifications, statistically significant, and of the expected signs. Such findings accord with earlier findings by Bennett and colleagues [24] and suggest that with improved collection 
of a wider range of more detailed household and local-level indicators of targeted forest ecosystem services delivery, especially for the FEDRC's ongoing monitoring data, a wealth of additional insights into the impacts of program design elements on ecological outcomes could be obtained with relatively little additional effort. The sheer scale and range of local conditions encompassed by the CCFP, furthermore, suggest that such insights could prove a treasure trove for both domestic and international policymakers and practitioners.

\section{Acknowledgments}

The survey from which the data in this article was drawn was made possible by support from the CCFP Social Economic Monitoring Project, China National Forestry Economics and Development Research Center (FEDRC) of the State Forestry Administration of China. We would specifically like to acknowledge the team members of the FEDRC (Huang Dong, Yuan Mei, Peng Wei) and Beijing Forestry University (Wu Tao, Tian Seng Nan, Xu Ding, Zhang Cao, Su Yue Xiu) who were involved in the survey design and data collection. The writing of this article was supported by the Center for International Forestry Research (CIFOR) using funds from the UK Department for International Development (DFID) KNOWFOR Programme, which aims "to increase the value and impact of forest and tree-related knowledge by improving dissemination, strengthening knowledge pathways and increasing uptake by key forest sector stakeholders such as policymakers and practitioners." The authors would also like to gratefully acknowledge the efforts of the anonymous reviewers and editors of the special issue for their contribution towards improving the paper.

\section{Author Contributions}

Chen Xie and Daoli Peng designed the survey instrument, while Daoli Peng, Tao Wu and Dong Huang implemented the survey. Chen Xie cleaned and organized the final dataset. Michael T. Bennett formulated and implemented the econometric strategy, and wrote up the section on the modeling results. Chen Xie, Nicholas J. Hogarth, Louis Putzel and Michael T. Bennett all contributed to final write up and interpretation of model results and implications.

\section{Conflicts of Interest}

The authors declare no conflict of interest.

\section{References}

1. Bennett, M.T. China's Sloping Land Conversion Program: Institutional Innovation or Business as Usual? Ecol. Econ. 2008, 65, 699-711.

2. Hyde, W.F.; Belcher, B.M.; Xu, J. China's Forests: Global Lessons from Market Reforms; Resources for the Future: Washington, DC, USA, 2003.

3. Liu, C. An Economic and Environmental Evaluation of the Natural Forest Protection Program; National Forest Economics and Development Research Center (FEDRC), State Forestry Administration (SFA): Beijing, China, 2002. 
4. Xu, J. The political, social, and ecological transformation of a landscape: The case of rubber in Xishuangbanna, China. Mount. Res. Dev. 2006, 26, 254-262.

5. China Council for International Cooperation on Environment and Development-Western China Forests and Grassland Task Force. In Implementing the Natural Forest Protection Program and the Sloping Land Conversion Program: Lessons and Policy Recommendations; Xu, J., Katsigris, E., White, T.A., Eds.; China Forestry Publishing House: Beijing, China, 2002.

6. Démurger, S.; Hou, Y.; Yang, W. Forest Management Policies and Resource Balance in China: An Assessment of the Current Situation; Groupe d'Analyse et de Théorie Economique (GATE), Ecole Normale Supérieure; Centre national de la recherche scientifique (CNRS): Lyon, France, 2007.

7. Démurger, S.; Hou, Y.; Yang, W. Forest management policies and resource balance in China: An assessment of the current situation. J. Environ. Dev. 2009, 18, 17-41.

8. SFA. Forestry Development Annual Report; China Forestry Publishing Press: Beijing, China, 2013.

9. Kelly, P.; Huo, X.X. Land Retirement and Nonfarm Labor Participation: An Analysis of China's Sloping Land Conversion Program. World Dev. 2013, 48, 156-169.

10. Xu, J.T.; Tao, R.; Xu, Z.G.; Bennett, M.T. China's Sloping Land Conversion Program: Does Expansion Equal Success? Land Econ. 2010, 86, 219-244.

11. Grosjean, P.; Kontoleon, A. How Sustainable and Sustainable Development Programs? The Case of the Sloping Land Conversion Program in China. World Dev. 2009, 37, 268-285.

12. Uchida, E.; Xu, J.; Xu, Z.; Rozelle, S. Are the poor benefiting from China's land conservation program? Environ. Dev. Econ. 2007, 12, 593-620.

13. Groom, B.; Grosjean, P.; Kontoleon, A.; Swanson, T.; Zhang, S. Relaxing constraints with compensation: Evaluating Off-farm labor responses to reforestation policy in China. In Proceedings of the Third World Congress of Environmental and Resource Economists, Kyoto, Japan, 2006.

14. Xie, C.; Zhao, Z.; Liang, D.; Zhang, L.; Dau, G.; Wang, X. Livelihood Impacts of the Conversion of Cropland to Forested Grassland Program. J. Environ. Plann. Manag. 2006, 49, 555-570.

15. Uchida, E.; Xu, J.T.; Rozelle, S. Grain for Green: Cost Effectiveness and Sustainability of China's Conservation Set-Aside Program. Land Econ. 2005, 81, 247-264.

16. Wang, X.H.; Bennett, J.; Xie, C.; Zhang, Z.T.; Dan, L. Estimating non-market environmental benefits of the conversion of cropland to forests and grassland program: A choice modeling approach. Ecol. Econ. 2006, 63, 114-125.

17. Xu, Z.G.; Bennett, M.T.; Tao, R.; Xu, J. China's Sloping Land Conversion Program Four Years On: Current Situation, Pending Issues. Int. For. Rev. 2004, 6, 317-326.

18. Deng, X.Z.; Huang, J.K.; Rozelle, S.; Uchida, E. Cultivated land conversion and potential agricultural productivity in China. Land Use Policy 2006, 23, 372-384.

19. Feng, Z.; Yang, Y.; Zhang, Y.; Zhang, P.; Li., Y. Grain-for-green policy and its impact on grain supply in west China. Land Use Policy 2005, 22, 301-312.

20. Xu, Z.; Xu, J.; Deng, X.; Huang, J.; Uchida, E.; Rozelle, S. Grain for green versus grain: Conflict between food security and conservation set-aside in China. World Dev. 2006, 34, 130-148. 
21. Weyerhaeuser, H.; Wilkes, A.; Kahrl, F. Local impacts and responses to regional forest conservation and rehabilitation programs in China, Äôs northwest Yunnan province. Agric. Syst. 2005, 85, 234-253.

22. Le, H.D.; Smith, C.; Herbohn, J.; Harrison, S. More than just trees: Assessing reforestation success in tropical developing countries. J. Rural Stud. 2012, 28, 5-19.

23. Chokkalingam, U.; Zaizhi, Z.; Chunfeng, W.; Toma, T. Learning Lessons from China's Forest Rehabilitation Efforts: National Level Review and Special Focus on Guangdong Province; Center for International Forestry Research (CIFOR): Bogor, Indonesia, 2006.

24. Bennett, M.T.; Mehta, A.; Xu, J. Incomplete property rights, exposure to markets and the provision of environmental services in China. China Econ. Rev. 2011, 22, 485-498.

25. He, J.; Lang, R.; Xu, J. Local Dynamics Driving Forest Transition: Insights from Upland Villages in Southwest China. Forests 2014, 5, 214-233.

26. Conversion of Cropland to Forests Program Plan (2001-2010); State Forestry Administration of the PRC: Beijing, China, 2003.

27. State Council Notice Regarding the Improvement of the Conversion of Cropland to Forests Policy; State Council of the PRC: Beijing, China, 2007.

28. Rozelle, S.; Brandt, L.; Guo, L.; Huang, J.K. Land Rights in China: Fact, Fiction and Issues. China J. 2002, 47, 67-97.

29. Zuo, T. Implementation of the SLCP. Implementing the Natural Forest Protection Program and the Sloping Land Conversion Program: Lessons and Policy Recommendations. In Implementing the Natural Forest Protection Program and the Sloping Land Conversion Program: Lessons and Policy Recommendations; Xu, J., Katsigris, E., White, T.A., Eds.; China Forestry Publishing House: Beijing, China, 2002.

30. Lamb, D. Regreening the Bare Hills: Tropical Forest Restoration in the Asia-Pacific Region; Springer: Heidelberg, Germany, 2010.

31. SFA. Criterion of Ecological and Economic Trees of the Conversion of Cropland to Forest Program; State Forestry Administration, CCFP Management Office: Beijing, China. 2001.

32. Hares, M. Perceptions of ethnic minorities on tree growing for environmental services in Thailand. In Smallholder Tree Growing for Rural Development and Environmental Services; Springer: Amsterdam, The Netherlands, 2008; pp. 411-425.

33. Mather, A. Recent Asian forest transitions in relation to forest-transition theory. Int. For. Rev. 2007, 9, 491-502.

34. Rudel, T.K. Tree farms: Driving forces and regional patterns in the global expansion of forest plantations. Land Use Policy 2009, 26, 545-550.

35. Meyfroidt, P.; Lambin, E.F. Forest transition in Vietnam and its environmental impacts. Glob. Change Biol. 2008, 14, 1319-1336.

36. Meyfroidt, P.; Lambin, E.F. Global forest transition: Prospects for an end to deforestation. Ann. Rev. Environ. Res. 2011, 36, 343-371.

37. Putzel, L.; Dermawan, A.; Moeliono, M.; Trung, L. Improving opportunities for smallholder timber planters in Vietnam to benefit from domestic wood processing. Int. For. Rev. 2012, 14, 227-237. 
38. Xu, J. China's new forests aren't as green as they seem. Nature 2011, 371, doi:10.1038/477371a.

(C) 2014 by the authors; licensee MDPI, Basel, Switzerland. This article is an open access article distributed under the terms and conditions of the Creative Commons Attribution license (http://creativecommons.org/licenses/by/3.0/). 